Journal of the Geological Society

Formation and emplacement of the Northland ophiolite, northern New Zealand: SW Pacific tectonic implications

Scott A. Whattam, John Malpas, Jason R. Ali, Ching-Hua Lo and lan E. M. Smith

Journal of the Geological Society 2005; v. 162; p. 225-241

doi:10.1144/0016-764903-167

Email alerting service

Permission request

Subscribe click here to receive free email alerts when new articles cite this article

click here to seek permission to re-use all or part of this article

click here to subscribe to Journal of the Geological Society or the Lyell Collection

Notes

Downloaded by National Taiwan University on 15 September 2009

(C) 2005 Geological Society of London

Lyell

Collection 


\title{
Formation and emplacement of the Northland ophiolite, northern New Zealand: SW Pacific tectonic implications
}

\author{
SCOTT A. WHATTAM ${ }^{1 *}$, JOHN MALPAS ${ }^{1}$, JASON R. ALI ${ }^{1}$, CHING-HUA LO $^{2}$ \& IAN E. M. SMITH \\ ${ }^{1}$ Department of Earth Sciences, University of Hong Kong, Pokfulam Road, Hong Kong, China \\ (e-mail:sawhatta@graduate.hku.hk) \\ ${ }^{2}$ Department of Geosciences, National Taiwan University, 245 Chousan Road, Taipei 106, Taiwan \\ ${ }^{3}$ Department of Geology, University of Auckland, Private Bag 92019, Auckland, New Zealand \\ *Present address: School of Earth and Environmental Sciences, Seoul National University, Seoul, 151-747, Korea
}

\begin{abstract}
Petrological, geochemical, geochronological and palaeomagnetic data for rocks of the Northland ophiolite terrane of northern New Zealand suggest that it formed in a suprasubduction-zone setting between $c$. 29 and $26 \mathrm{Ma}$, at $c .35^{\circ} \mathrm{S}$, close to its Late Oligocene obduction site. Cretaceous igneous rocks formerly considered to be part of the ophiolite probably represent the basement upon which the ophiolite was emplaced, and are probably part of the Mount Camel arc-related terrane. The ophiolite is believed to have been generated in the southeastern South Fiji Basin, close to a NW-SE-oriented transform fault located to the SW of the Vening Meinesz Fracture Zone, and was probably emplaced in response to the collision of the Hikurangi Plateau with eastern New Zealand at the end of the Oligocene. This collision would have involved a major adjustment on the transform fault, thereby allowing a portion of the upper-crustal section of the southern South Fiji Basin to be emplaced southwestward onto northern New Zealand as well as the coeval emplacement of the East Cape Allochthon to the south. Concomitant subduction of the lower crust-mantle section led to the initiation of arc volcanism that resulted in the Northland Lower Miocene volcanic-plutonic suite.
\end{abstract}

Keywords: SW Pacific, Northland ophiolite, tectonics, palaeomagnetism, absolute age.

The 100-0 Ma tectonic evolution of the SW Pacific region has been complex (Yan \& Kroenke 1993; Hall 2002). In the Early Cretaceous, the eastern edge of the Australian Plate formed a convergent boundary against which various 'Pacific' oceanic terranes were accreted. From about 80 to $55 \mathrm{Ma}$, eastern Gondwana experienced large-scale extension and fragmentation, and a number of ribbon-like slivers of Australian basement simultaneously separated from the margin extending the Australian Plate $>2000 \mathrm{~km}$ eastward (Falvey \& Mutter 1981; Gaina et al. 1998). In the Palaeogene, the eastern edge of the plate became a convergent boundary and oceanic terranes were accreted against the Australian Plate at various stages in eastern New Guinea, New Caledonia and northern New Zealand (Malpas et al. 1992, 1994). Since the beginning of the Neogene, the system has continued to evolve, particularly in the formation of the three-ridge spreading system in the West Fiji Basin and with development of the Lau (back-arc) Basin.

\section{Geological setting}

The Northland ophiolite of northern New Zealand (Fig. 1) comprises massifs of mainly basaltic volcanic rocks, which form the upper thrust slices of the Northland Allochthon. It represents a key fragment in a commonly accepted regional model (Aubouin et al. 1977; Walcott 1978; Parrot \& Dugas 1980), where it forms the youngest emplaced segment of an almost continuous Late Cretaceous-Eocene oceanic belt that collided with eastern Gondwana diachronously, starting in the north in New Guinea in the Palaeocene (Davis 1971) followed by New Caledonia in the latter part of the Eocene (Ali \& Aitchison 2000). However, to understand the role of the Northland ophiolite in the development of the
SW Pacific, a number of points need to be addressed, including the tectonic setting in which it formed, when and where it formed, and how it relates to other regional tectonic elements.

Despite the efforts of various workers (Malpas et al. 1992; Cassidy 1993; Nicholson et al. 2000a, b) a clear consensus on the origin of the Northland ophiolite has not yet emerged. One of the biggest questions concerns its age. Traditionally, it has been accepted that the ophiolite formed in the Late Cretaceous to Palaeocene, based on micro- and macrofaunas recovered from a number of massifs (Farnell 1973; Brook et al. 1988; Larsen \& Spörli 1989; Hollis \& Hanson 1991). Until recently, radiometric dates have been based on $\mathrm{K}$-Ar dating methods, but the large spread of ages (100-42 Ma) (Brothers \& Delahoye 1982) has made their interpretation and synthesis difficult in a tectonic model. The problem with a c. 80-55 Ma fossil-age spread for the generation of the ophiolite is that it is difficult to develop a plate model that places such old oceanic crust adjacent to northern New Zealand in the Late Oligocene (Malpas et al. 1992). In an attempt to resolve this conundrum, we have carried out multidisciplinary research involving field studies, radiometric dating, geochemistry, palaeontology and palaeomagnetism. (For example, geochemical data clearly indicate that all rocks mapped as ophiolite formed in suprasubduction-zone environments (Hopper \& Smith 1996; Thompson et al. 1997; Whattam 2003). The geochemical data, however, when placed in a regional context and matched with other nearby volcanic bodies (e.g. Mount Camel Volcanics, and possibly the (?)Cretaceous Hikurangi Plateau basalts) (Kamp 1986), together with our radiometric data, suggest that the Northland ophiolite, as it is currently mapped, represents two distinct units; one relatively minor group of rocks that formed in the Late Cretaceous and the main part of 


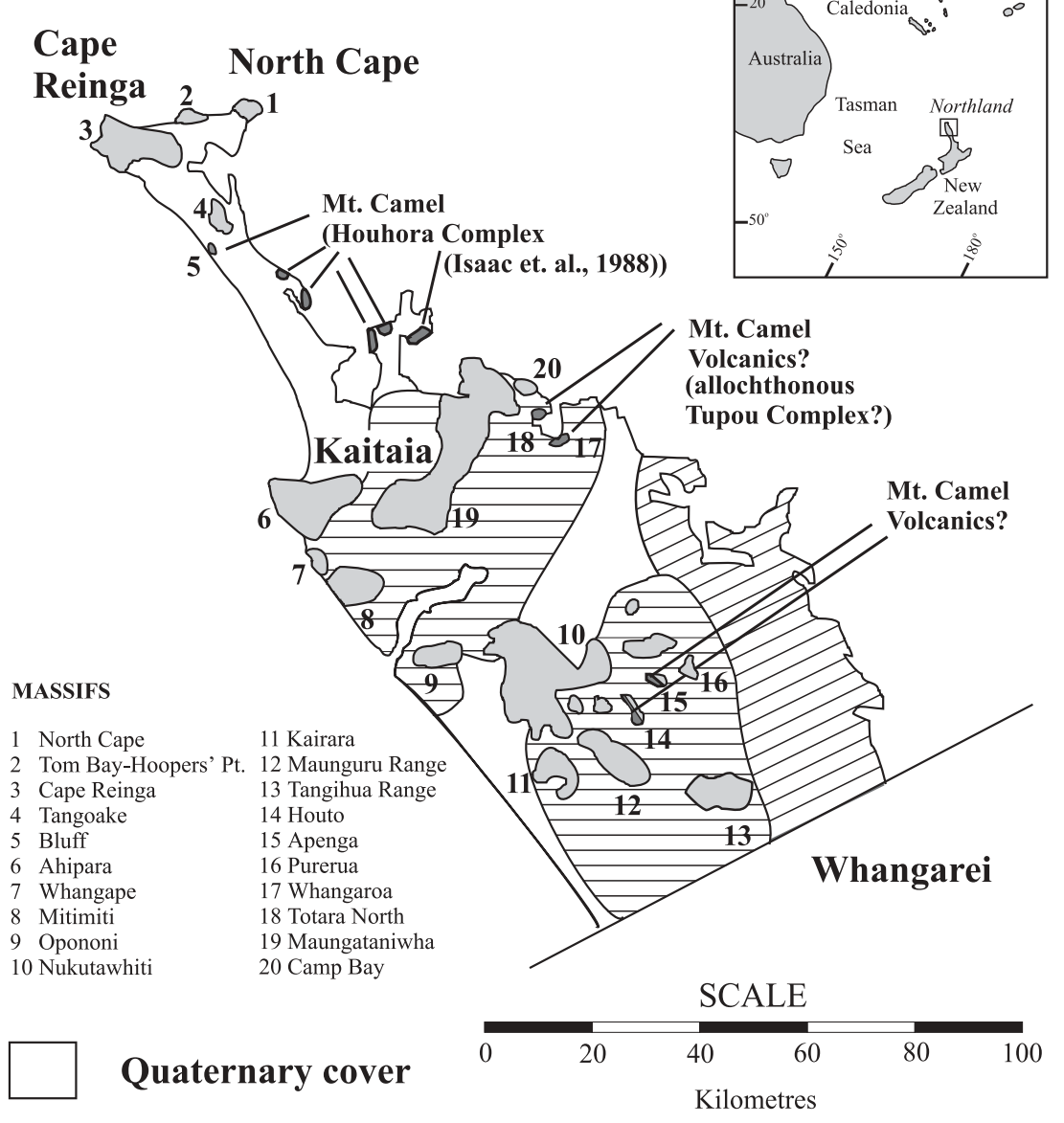

Northland ophiolite massifs

Cretaceous-Oligocene sedimentary rocks

\section{Cretaceous arc volcanic rocks (as defined by this study)}

\section{Permian-Jurassic Torlesse Supergroup metagreywacke}

Fig. 1. Simplified geological map of northern New Zealand showing the location of the Northland ophiolite and Cretaceous arc-related outcrops sampled for geochemical and geochronological analyses. Inset shows location of Northland in the SW Pacific with respect to New Caledonia and Papua New Guinea. the allochthonous igneous terrane that formed in the Late Oligocene).

\section{Field exposures}

\section{Northland ophiolite}

Outcrops consist primarily of basaltic pillow lavas and less common sheet flows. Basalt dominates with subordinate diabase and gabbro, together with minor alkalic rocks (Larsen \& Parker 1989; Malpas et al. 1992; Thompson et al. 1997). Rare ultramafic rocks crop out at North Cape (Bennett 1976) (Fig. 1) and include a variety of lithologies including serpentinite, cumulate harzburgite and lherzolite, olivine clinopyroxenite, wehrlite dykes and hornblendite (Malpas et al. 1992). In addition, minor intermediate and acid intrusive rocks that include diorite, quartz diorite and plagiogranite form part of the terrane (Malpas et al. 1992; Thompson et al. 1997). The plagiogranites are present as irregular dykes and micro-sills intruded into the high-level gabbros of the ophiolite.

\section{Cretaceous arc-related rocks}

Rare volcaniclastic rocks are exposed in two small (c. 
$10 \mathrm{~m} \times 10 \mathrm{~m}$ ) outcrops on the NE coast near Whangaroa (massif 17, Fig. 1). Alkalic basalts are confined to the lowest exposed stratigraphic level of the Apenga massif in south-central Northland and are overlain by tholeiitic basalts. Transitional basalts consist of sheet flows and less common pillows and are restricted to the Bluff massif on the west coast between Ahipara and Cape Reinga (massif 5, Fig. 1). The volcaniclastic rocks and the transitional basalts probably represent an extension of the Mount Camel basement terrane (Isaac et al. 1988). The alkalic basalts may represent the southernmost extension of, or a unique basement terrane different from that of, the Mount Camel terrane.

\section{Petrology}

Petrological differences between the ophiolite and arc-related rocks are readily apparent. Tholeiitic basalts of the Northland ophiolite comprise primarily labradorite (phenocryst cores $\mathrm{An}_{59}-$ 72, groundmass cores $\mathrm{An}_{60}-{ }_{63}$ ), augite (phenocryst cores $\mathrm{Wo}_{30}-$ ${ }_{37} \mathrm{En}_{35}-{ }_{50} \mathrm{Fs}_{12}-19$, groundmass cores $\mathrm{Wo}_{35}-{ }_{41} \mathrm{En}_{40}-{ }_{52} \mathrm{Fs}_{11}-22$ ) and magnetite with rare orthopyroxene and olivine. They display textures characteristic of submarine basalt and exhibit secondary alteration phases typical of hydrothermally altered submarine volcanic rocks, i.e. chlorite, epidote, palagonite and zeolites (stilbite-laumonite).

Basaltic intrusive equivalents of the tholeiitic basalt include diabase and gabbro, and intermediate and acid differentiates of diorite and plagiogranite. As with the basalts, the diabase and gabbro comprise primarily plagioclase, clinopyroxene and magnetite. Gabbro plagioclase is bytownite $\left(\mathrm{An}_{78}-86\right)$ whereas diabase plagioclase is essentially labradorite $\left(\mathrm{An}_{66}-{ }^{-71}\right)$. Augite is the clinopyroxene in both the gabbro and diabase. The diorites consist of andesine $\left(\mathrm{An}_{20}-{ }_{52}\right)$, amphibole (cummingtonite), quartz, rare augite and titaniferous magnetite. Plagiogranite is composed of albite $\left(\mathrm{An}_{3}-5\right)$, quartz, rare amphibole and augite, chlorite, amphibole and titaniferous magnetite. Micrographic textures are well developed in the plagiogranite manifest as granophyric intergrowths of albite and quartz. The plagioclase compositions decrease in $\mathrm{Ca}$ and sympathetically increase in $\mathrm{Na}$ with increasing fractionation from gabbro to diorite and to plagiogranite.

The transitional basalts of the arc-related suite are best classified as spilites or keratophyres (the volcaniclastic rocks are interpreted to represent reworked transitional basalt). The spilites comprise albite (phenocryst cores $\mathrm{An}_{2}-5$, groundmass cores $\mathrm{An}_{2}-6$ ), rare green, pleochroic augite (phenocrysts $\mathrm{Wo}_{30}-$ ${ }_{35} \mathrm{En}_{42}-{ }_{44} \mathrm{Fs}_{20}-26$ ), chlorite, potassium feldspar and titanite (grothite). Clinopyroxene is absent from the groundmass.

The ophiolite-related alkalic basalt consists of labradorite (phenocryst cores $\mathrm{An}_{54-59}$, groundmass cores $\mathrm{An}_{63}-69$ ), pink, pleochroic titanaugite phenocrysts (cores $\mathrm{Wo}_{37}-{ }_{43} \mathrm{En}_{45}-{ }_{49} \mathrm{Fs}_{13}-$ 16) and groundmass diopside (cores $\mathrm{Wo}_{50} \mathrm{En}_{31} \mathrm{Fs}_{19}$ ), ubiquitous olivine pseudomorphs composed of calcite and iddingsite, amphibole and magnetite. The arc-related alkalic basalts are grossly similar to those from the ophiolite; however, olivine pseudomorphs are absent, the groundmass clinopyroxene composition is different (augite $\mathrm{Wo}_{44} \mathrm{En}_{30} \mathrm{Fs}_{26}$ ), with lower $\mathrm{TiO}_{2}$ contents (2$3 \mathrm{wt} \%$ v. 5-6 wt $\%$ ), and amphibole is absent.

\section{Geochemistry}

\section{Analytical techniques}

Some 120 samples collected from 20 massifs (Fig. 1) were cleaned and crushed in an agate mill. Major element abundances were obtained by standard XRF techniques (Norris \& Chappell 1977) at the Department of Geology, University of Auckland. Certain trace element abundances (all except $\mathrm{Hf}, \mathrm{Ta}, \mathrm{Nb}$ ) were determined on pressed pellets by XRF at the University of Hong Kong. A subset of 62 whole-rock samples were dissolved in hydrochloric and nitric acid and analysed by means of inductively coupled plasma mass spectrometry (ICP-MS) at the University of Hong Kong to determine selected trace element (Hf, $\mathrm{Ta}, \mathrm{Nb}$ ) and REE concentrations. Complete analyses of volcanic and plutonic rocks of the Northland ophiolite and the Cretaceous arc are available from the British Library Document Supply Centre, Boston Spa, Wetherby, West Yorkshire LS23 7BQ, UK as Supplementary Publication No. SUP 18213 (3 pages). It is also available online at http://www.geolsoc.org.uk/SUP18213.

\section{Results}

Hopper \& Smith (1996) were the first to detect a suprasubduction-zone signature for rocks forming the Northland ophiolite based on their geochemical study of gabbros and sheeted basaltic intrusive rocks from North Cape in the far north of Northland (Fig. 1). Research conducted by Thompson et al. (1997) on plutonic rocks, and Nicholson et al. $(2000 a, b)$ on tholeiitic basaltic rocks of the Northland ophiolite corroborate the findings of Hopper \& Smith (1996). Geochemical data from this study further substantiate these findings (Fig. 2a and b). An important feature of our dataset is that it is the first to unequivocally show that previously mapped rocks of the ophiolite can be subdivided not only on the basis of petrological and geochemical characteristics, but also by geochronology.

Like the normal mid-ocean ridge basalt (N-MORB)-normalized signature displayed by the ophiolite basalts, the volcaniclastic rocks have a prominent negative $\mathrm{Nb}$ anomaly with respect to Th and Ce but display higher N-MORB-normalized concentrations of $\mathrm{Nb}$ (Fig. 2c). This pattern of higher concentrations of $\mathrm{Nb}$ and $\mathrm{Zr}$ but lower concentrations of $\mathrm{Ti}$ and $\mathrm{Y}$ relative to N-MORB is typical of calc-alkaline arc basalts (Pearce 1982).

Chondrite-normalized REE patterns for all volcanic rocks are shown in Figure 3. The Northland ophiolite basalts are light REE (LREE) depleted, of generally low concentration (maximum $40 \times$ chondrite), indicative of an N-MORB-like depleted magma source (Fig. 3a). The alkalic basalts display LREE and middle REE (MREE) enrichment (Fig. 3b). A single sample shows LREE enrichment not present in the tholeiitic basalt samples, suggesting that it is unrelated to these basalts. In stark contrast to the tholeiitic basalts, the volcanic rocks of the arc-related suite display significant LREE and moderate MREE enrichment, suggesting formation by melting of an LREE-enriched source (Fig. 3c).

\section{Plagiogranite chemistry}

Figure $2 \mathrm{~d}$ shows the similarity of N-MORB-normalized patterns of the diorites and dated plagiogranite sample NUKU 19.1 to those of the ophiolite gabbroic suite. Negative $\mathrm{P}$ and $\mathrm{Ti}$ anomalies suggest apatite and $\mathrm{Fe}-\mathrm{Ti}$ oxide fractionation. Shown in Figure $3 \mathrm{~d}$ is the chondrite-normalized REE composition of the dated plagiogranite (sample NUKU 19.1), the less evolved diorites and the 'parent' gabbroic suite. The largely flat REE pattern of the diorite and plagiogranite with minor LREE depletion is identical to that of the ophiolite gabbroic 'parent' suite from which it differentiated, and is typical of plagiogranites in general (Coleman \& Donato 1979). Its pattern is similar to signatures reported for plagiogranites from other ophiolite complexes (e.g. the Karmoy ophiolite, Pedersen \& Malpas 1984; the Sarikaraman ophiolite, Floyd et al. 1998) and has been shown to represent extreme fractional crystallization from a hydrous gabbroic source (Pedersen \& Malpas 1984). 

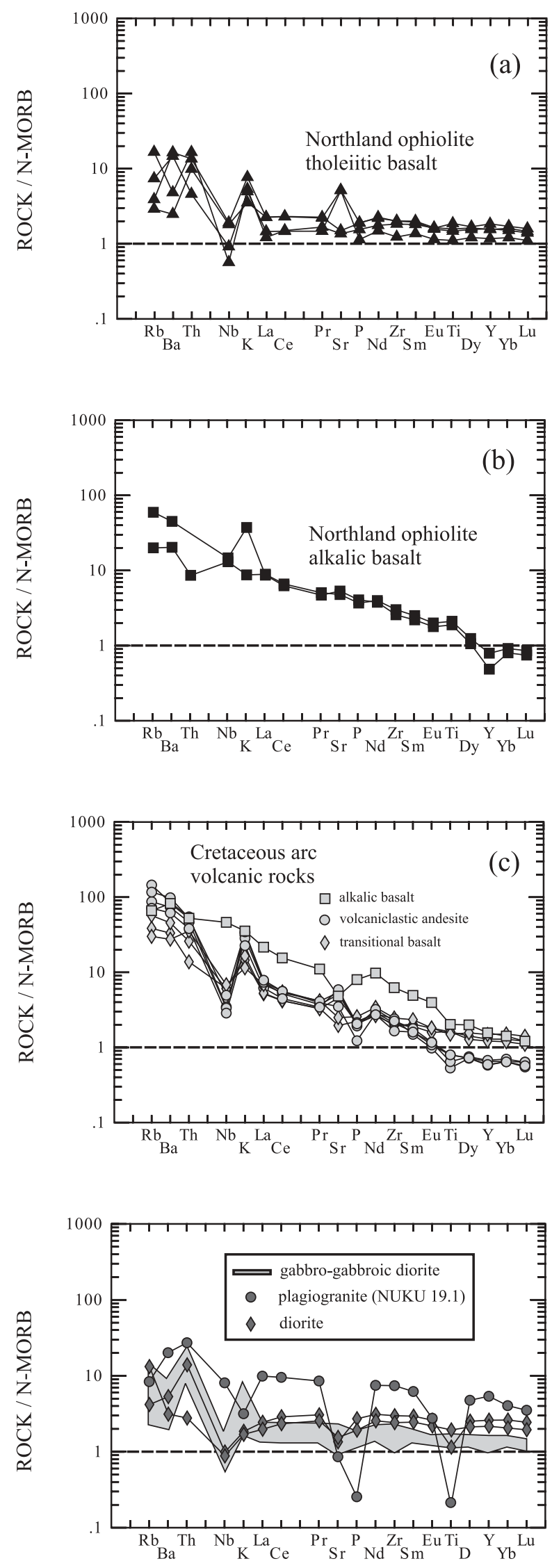

Fig. 2. N-MORB-normalized patterns for all rocks from this study. MORB concentrations are from Sun \& McDonough (1989).

\section{Tectonic affinities}

The N-MORB-normalized concentrations of the tholeiitic rocks display a negative $\mathrm{Nb}$ anomaly and an enrichment in large ion lithophile elements (LILE). These two features are indicative of formation in a suprasubduction-zone environment. This is confirmed in the Th-Hf-Ta diagram of Wood (1980) (Whattam 2003). The differences between the ophiolite and Cretaceous arcrelated rocks are shown in Figure 4. Also, the tholeiitic basalts plot almost entirely as back-arc basin basalts, with some overlap into the volcanic-arc tholeiite field in the $\mathrm{La}-\mathrm{Y}-\mathrm{Nb}$ diagram of Cabanis \& Lecolle (1989). Conversely, the arc-related basalts and volcaniclastic andesites plot as continental basalts and continental arc basalts, respectively (Whattam 2003).

The likelihood of formation in a back-arc environment for the ophiolite tholeiitic basalts is established when a comparison of their N-MORB-normalized patterns is made with suprasubduction-zone lavas of the Lau back-arc basin (data compiled by Meffre et al. (1996) and Whattam (2003)). The morphology of the patterns is similar, with comparable LILE enrichment; however, the Northland ophiolite basalts display slighter high field strength element (HFSE) depletions. When Ti/Zr v. Zr (ppm) concentrations of the tholeiitic basalts are compared with western Pacific back-arc-volcanic-arc pairs, their composition is similar to the former (Whattam 2003), particularly basalts of the North Fiji back-arc basin (data compiled by Knittel \& Oles (1995)).

\section{SHRIMP U-Pb analysis of plagiogranite zircons}

\section{Analytical technique}

Zircons were separated from plagiogranite sample NUKU 19.1 by conventional crushing, sizing, magnetic and density methods before being mounted in epoxy, polished and gold coated. Mounts were then photographed in transmitted and reflected light for identification of analysed grains. Cathodoluminescence images were obtained on a JEOL SEM.

The instrumental techniques for isotopic analysis of zircons using the Curtin sensitive high-resolution ion microprobe (SHRIMP II) are akin to those of Compston et al. (1984). Fifteen 564 Ma standard zircons (CZ3) were interspersed between the 25 plagiogranite zircons. All isotopic measurements were reduced by off-line computer programs using standard techniques. Data reduction was done with in-house programs Krill and Plonk. Krill is based on Prawn from the Research School of Earth Sciences (RSES) at the Australian National University (ANU) and Plonk is the plotting program that gives statistics for the reduced data. $\mathrm{Pb}-\mathrm{U}$ ages were normalized to a value of $564 \mathrm{Ma}$ determined by conventional $\mathrm{U}-\mathrm{Pb}$ analysis of the standard zircon $\mathrm{CZ3}$. The measurement of ${ }^{206} \mathrm{~Pb} /{ }^{238} \mathrm{U}$ and ${ }^{207} \mathrm{~Pb} /{ }^{235} \mathrm{U}$ ages requires normalization to the results of our standard analyses and the ${ }^{206} \mathrm{~Pb} /{ }^{238} \mathrm{U}$ and ${ }^{207} \mathrm{~Pb} /{ }^{235} \mathrm{U}$ data have been corrected for uncertainties associated with the measurements of the CZ3 standard. The ${ }^{207} \mathrm{~Pb} /{ }^{206} \mathrm{~Pb}$ ages given in Table 1 are independent of our standard analyses. The age of zircons in NUKU 19.1 is young, c. $30 \mathrm{Ma}$, and the ${ }^{206} \mathrm{~Pb} /{ }^{238} \mathrm{U}$ age is the best estimate of the true age. Common $\mathrm{Pb}$ was corrected using the 204 method discussed by Compston et al. (1984).

\section{Results}

Sample NUKU 19.1 contains zircons with a variety of textures that display a highly complex internal structure. Many crystals are equant, and most contain well-defined sector zones although there are some small overgrowths on the exterior of the crystals. However, the internal complexity of the zircons does not affect the ages obtained from different grains. Cores, rims, high and low $U$ concentration regions, and crystals of different morph- 
ology, all give the same age within the analytical uncertainties. The mean ${ }^{206} \mathrm{~Pb} /{ }^{238} \mathrm{U}$ age, based on 24 analyses, is $28.3 \pm 0.2 \mathrm{Ma}$, where the uncertainty is the $2 \sigma$ error on the mean. The results are slightly discordant, with a mean ${ }^{207} \mathrm{~Pb} /{ }^{235} \mathrm{U}$
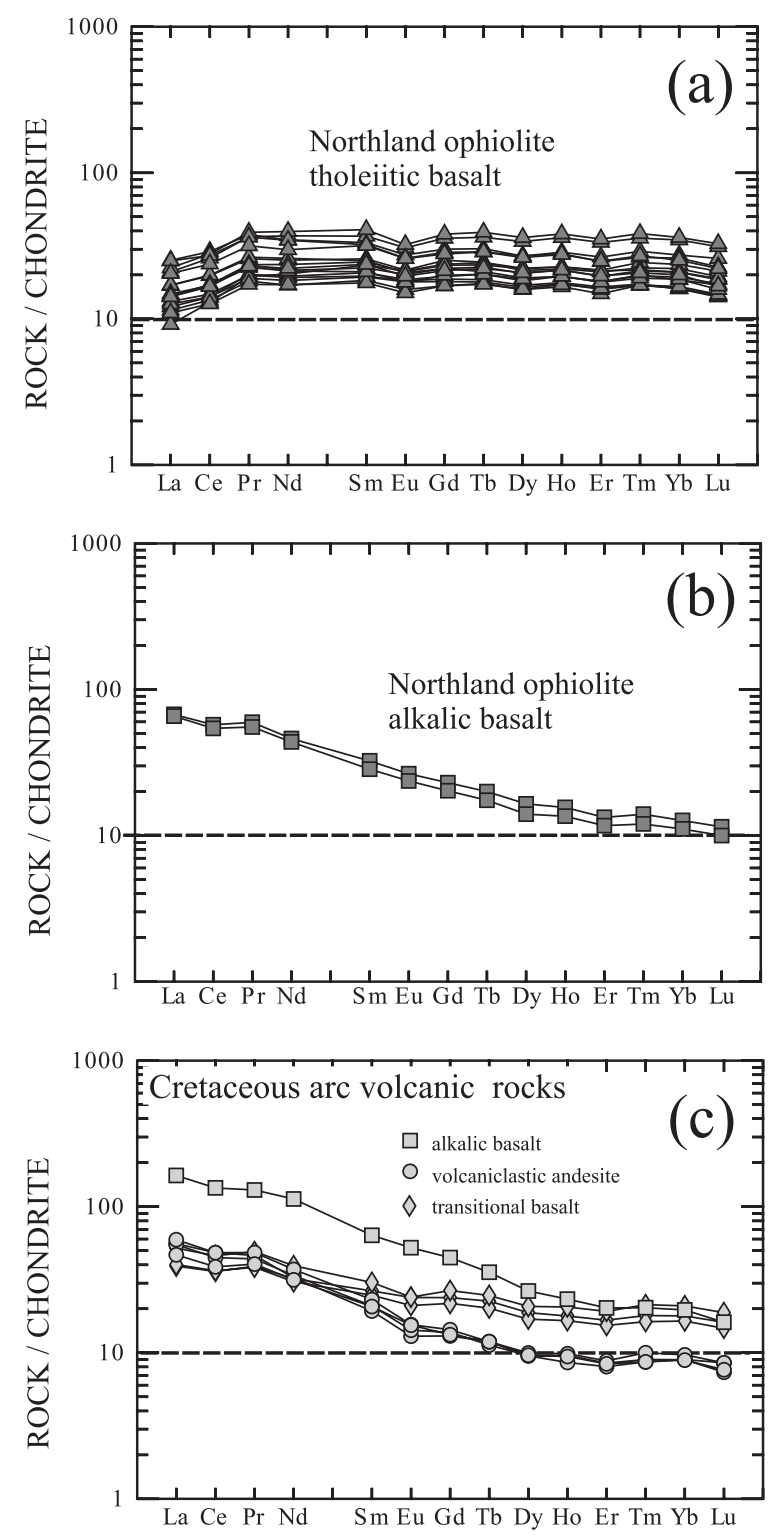

age of $30.2 \pm 0.7 \mathrm{Ma}$. The mean ${ }^{207} \mathrm{~Pb} /{ }^{206} \mathrm{~Pb}$ age is poorly constrained and cannot be used. The data are consistent with there being a single age population of zircons. The $\chi^{2}$ value for the ${ }^{206} \mathrm{~Pb} /{ }^{238} \mathrm{U}$ age is 0.73 , for 24 analyses, and for the ${ }^{207} \mathrm{~Pb} /$ ${ }^{235} \mathrm{U}$ age it is 0.69 . These values indicate that the zircons are from a single Gaussian distribution. Figure 5 is a concordia plot of all of the data and shows a single group of concordant zircons. In the inset of Figure 5, the discordant zircon of Figure 5 has been removed, so that the data for the other grains can be shown on an expanded scale. There is no age difference between the low and high $U$ concentration analyses and no evidence of disturbance since $28 \mathrm{Ma}$.

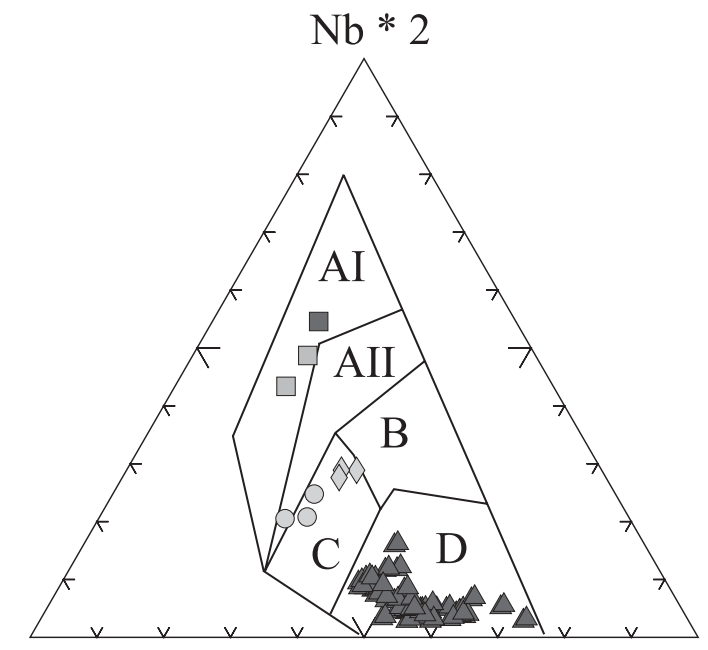

$\mathrm{Zr} / 4$
$\mathrm{AI}=\mathrm{WPA}$
$\mathrm{C}+\mathrm{D}=\mathrm{VAB}$
$\mathrm{AII}+\mathrm{C}=\mathrm{WPT}$
$\mathrm{D}=\mathrm{N}-\mathrm{MORB}$ $\mathrm{B}=\mathrm{P}-\mathrm{MORB}$

Fig. 4. Tectonic affinities of rocks of the Northland ophiolite and the Cretaceous arc. Fields from Meschede (1986). Subdivisions are as follows: AI, within-plate alkalic; AII + C, within-plate tholeiitic; B, enriched MORB; C + D, volcanic-arc basalt; D, normal MORB.

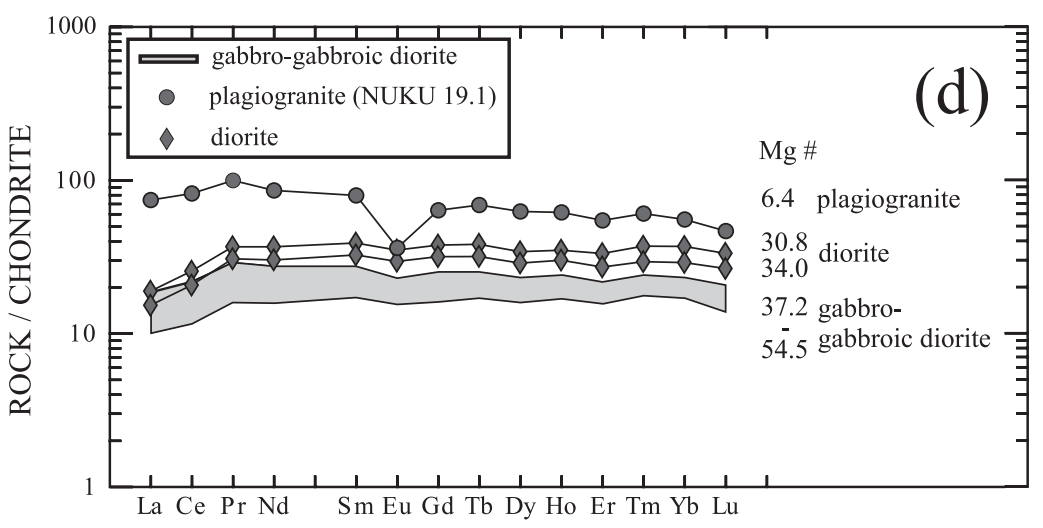

Fig. 3. Chondrite-normalized patterns for all rocks from this study. Chondrite concentrations are from Nakamura (1974). 
Table 1. Ion microprobe analytical $U-T h-P b$ data for zircons separated from plagiogranite sample NUKU 19.1

\begin{tabular}{|c|c|c|c|c|c|c|c|c|}
\hline Spot & $\mathrm{U}(\mathrm{ppm})$ & Th (ppm) & $\mathrm{Pb}(\mathrm{ppm})$ & Conc. (\%) & $\begin{array}{c}{ }^{206} \mathrm{~Pb} /{ }^{238} \mathrm{U} \text { age } \\
\text { (Ma) }\end{array}$ & $\begin{array}{c}{ }^{207} \mathrm{~Pb} /{ }^{235} \mathrm{U} \text { age } \\
\text { (Ma) }\end{array}$ & $\begin{array}{c}{ }^{207} \mathrm{~Pb} /{ }^{206} \mathrm{~Pb} \text { age } \\
\text { (Ma) }\end{array}$ & $\begin{array}{c}{ }^{208} \mathrm{~Pb} /{ }^{232} \mathrm{Th} \text { age } \\
\text { (Ma) }\end{array}$ \\
\hline NUKU 1 & 1131 & 2055 & 7 & 13 & $28.5 \pm 0.4$ & $31 \pm 3$ & $219 \pm 264$ & $29 \pm 1$ \\
\hline NUKU 3 & 637 & 768 & 4 & 0 & $28.8 \pm 0.8$ & $26 \pm 12$ & $0 \pm 60$ & $27 \pm 4$ \\
\hline NUKU 4 & 264 & 250 & 1 & 0 & $27.5 \pm 1.0$ & $23 \pm 18$ & $0 \pm 81$ & $26 \pm 7$ \\
\hline NUKU 5 & 488 & 459 & 3 & 1 & $30.6 \pm 0.4$ & $95 \pm 3$ & $2340 \pm 52$ & $54 \pm 2$ \\
\hline NUKU 6 & 1434 & 2706 & 9 & 69 & $28.4 \pm 0.4$ & $28 \pm 3$ & $41 \pm 262$ & $27 \pm 1$ \\
\hline NUKU 9 & 1568 & 3416 & 10 & 0 & $28.5 \pm 0.4$ & $23 \pm 6$ & $0 \pm 39$ & $27 \pm 1$ \\
\hline NUKU 10 & 1535 & 5203 & 13 & 28 & $29.0 \pm 0.3$ & $30 \pm 3$ & $103 \pm 230$ & $28 \pm 1$ \\
\hline NUKU 12 & 743 & 1591 & 6 & 0 & $27.9 \pm 0.8$ & $20 \pm 12$ & $0 \pm 41$ & $30 \pm 2$ \\
\hline NUKU 11 & 119 & 85 & 1 & 25 & $28.1 \pm 2.0$ & $29 \pm 34$ & $113 \pm 1610$ & $28 \pm 18$ \\
\hline NUKU 13 & 1565 & 3486 & 10 & 0 & $28.1 \pm 0.3$ & $27 \pm 3$ & $0 \pm 37$ & $27 \pm 1$ \\
\hline NUKU 14 & 624 & 728 & 3 & 28 & $28.3 \pm 0.5$ & $29 \pm 6$ & $102 \pm 457$ & $27 \pm 1$ \\
\hline NUKU 15 & 1448 & 2713 & 9 & 0 & $28.0 \pm 0.3$ & $26 \pm 3$ & $0 \pm 42$ & $26 \pm 1$ \\
\hline NUKU 20 & 549 & 592 & 3 & 10 & $27.9 \pm 0.4$ & $31 \pm 1$ & $286 \pm 67$ & $29 \pm 1$ \\
\hline NUKU 21 & 629 & 717 & 3 & 0 & $28.3 \pm 0.6$ & $28 \pm 8$ & $0 \pm 56$ & $26 \pm 3$ \\
\hline NUKU 22 & 1000 & 1514 & 6 & 19 & $28.1 \pm 0.3$ & $30 \pm 1$ & $145 \pm 52$ & $27 \pm 1$ \\
\hline NUKU 23 & 759 & 1215 & 5 & 17 & $28.7 \pm 0.3$ & $30 \pm 1$ & $167 \pm 58$ & $29 \pm 1$ \\
\hline NUKU 24 & 1420 & 2796 & 9 & 19 & $28.3 \pm 0.3$ & $30 \pm 1$ & $148 \pm 42$ & $27 \pm 0$ \\
\hline NUKU 25 & 667 & 754 & 4 & 0 & $28.0 \pm 0.5$ & $25 \pm 7$ & $0 \pm 62$ & $26 \pm 2$ \\
\hline
\end{tabular}

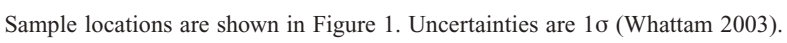

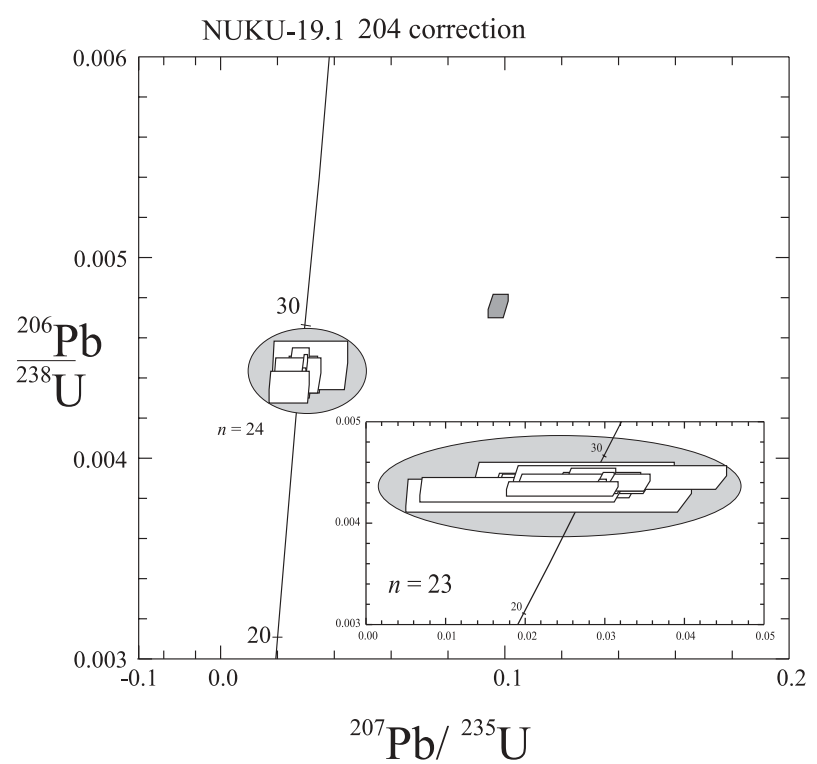

Fig. 5. Concordia plot of all the SHRIMP $\mathrm{U}-\mathrm{Pb}$ analytical data of plagiogranite sample NUKU 19.1 and (inset) an expanded version with removal of the lowest $U$, largest uncertainty zircon, and the discordant zircon in the main figure.

\section{${ }^{40} \mathrm{Ar} /{ }^{39} \mathrm{Ar}$ step-heating \\ Analytical techniques}

Only samples that were fresh with little or no evidence of alteration (under the microscope) were selected for the step-heating argon analysis. Where present, secondary veinlets and alteration products were meticulously removed. Basalt samples were crushed to $2-3 \mathrm{~mm}$ pieces after which they were ultrasonically cleaned. The samples, weighing between 50 and $100 \mathrm{~g}$, were wrapped in aluminium foil packets before being stacked longitudinally in the aluminium irradiation cans, which are $c$. $105 \mathrm{~mm}$ long and $25 \mathrm{~mm}$ in diameter. For monitoring the gradient of neutron flux and obtaining $J$ values for the age calculation of the samples, three or more packets containing suitable standard minerals, in this case LP-6 biotite, having a K-Ar age of $127.7 \pm 1.4 \mathrm{Ma}$ (Odin et al. 1982) were stacked with the samples in the same canister. The samples were irradiated along with the LP-6 biotite standard with $\mathrm{K}-\mathrm{Ar}$ age of $127.7 \pm 1.4 \mathrm{Ma}$ (Odin et al. 1982) in the VT-C position at the THOR Reactor in Taiwan for $30 \mathrm{~h}$. After irradiation, the samples were fused using a resistance furnace, and the gas was analysed using a Varian-MAT GD150 mass spectrometer at the National Taiwan University. The mean of the $J$ values obtained from the monitor standards was adopted in the age calculations because the gradient of neutron flux across the canister was rather small. The isotope interferences caused by $\mathrm{Ca}, \mathrm{K}$ and $\mathrm{Cl}$ were monitored by analytical results for the co-irradiated salts. Ages were calculated from $\mathrm{Ar}$ isotopic ratios after corrections had been made for mass discrimination, interfering nuclear reactions, procedural blanks and atmospheric Ar contamination. Analytical procedures have been outlined in detail by Lo \& Lee (1994). Results of the ${ }^{40} \mathrm{Ar} /{ }^{39} \mathrm{Ar}$ analyses are shown in Table 2, examples of plotted age spectrum diagrams are shown in Figure 6, and the data are summarized in Table 3.

\section{Results}

Samples were categorized and interpreted based on the morphology of age spectra procured, which reflects the phases present in the rocks. The age spectrum morphologies can be broadly divided into two 'types', the characteristics of which are described below.

Type 1 age spectrum morphology. Samples of this type are among the freshest (based on microsopic observation) of the ophiolite suite, although minor alteration is apparent as uralite after clinopyroxene and palagonite after glass. Plateaux exist between the lowest temperature steps $\left(450-500{ }^{\circ} \mathrm{C}\right)$ and inter- 
Table 2. ${ }^{40} \mathrm{Ar}{ }^{\beta 9} \mathrm{Ar}$ data for samples that yield plateau dates

\begin{tabular}{|c|c|c|c|c|c|c|c|c|}
\hline Sample & Assn. & Type & Rock type & $\begin{array}{l}\% \text { of }{ }^{39} \mathrm{Ar} \\
\text { released (for } \\
\text { given plateau) }\end{array}$ & $\begin{array}{l}\text { Plateau temp. } \\
\left({ }^{\circ} \mathrm{C}\right)\end{array}$ & $\begin{array}{l}\text { Plateau age } \\
\text { (Ma) }\end{array}$ & $\begin{array}{l}\text { Isochron age } \\
\text { (Ma) }\end{array}$ & ${ }^{40} \mathrm{Ar} /{ }^{36} \mathrm{Ar}$ \\
\hline MITI $2.1^{*}$ & NO & 2 & Thol. basalt & 88 & $750-1150$ & $28.3 \pm 3.4$ & $27.1 \pm 1.5$ & $296.6 \pm 1.1$ \\
\hline NUKU 5.1 & NO & 1 & Thol. basalt & 94 & $500-970$ & $26.2 \pm 0.6$ & $24.3 \pm 1.8$ & $315.9 \pm 5.9$ \\
\hline NUKU 6.1* & NO & 2 & Thol. basalt & 82 & $650-1080$ & $28.8 \pm 0.5$ & $27.9 \pm 1.5$ & $302.5 \pm 16.3$ \\
\hline OPO 3.2 & NO & 1 & Thol. diabase & 95 & $500-1000$ & $25.1 \pm 1.2$ & $24.6 \pm 4.1$ & $293.1 \pm 17.5$ \\
\hline WHGP $4.1^{*}$ & NO & 2 & Thol. basalt & 74 & $500-1050$ & $29.6 \pm 1.0$ & $31.1 \pm 1.0$ & $289.0 \pm 4.4$ \\
\hline $43555(\mathrm{CB})^{*}$ & NO & 2 & Thol. basalt & 77 & $450-1020$ & $29.3 \pm 0.7$ & $30.1 \pm 1.1$ & $296.6 \pm 6.8$ \\
\hline TA 15 & $\mathrm{NO}$ & n.a. & Alk. basalt & 99 & $725-1200$ & $25.0 \pm 0.8$ & $27.5 \pm 0.4$ & $263.6 \pm 19.3$ \\
\hline TOTA 1.1 & $\mathrm{CA}$ & n.a. & $\begin{array}{l}\text { Calc.-alk. } \\
\text { volcaniclastic }\end{array}$ & 71 & $590-1020$ & $109.0 \pm 0.7$ & $107.3 \pm 2.4$ & $358.8 \pm 0.7$ \\
\hline WHANG 1.1 & $\mathrm{CA}$ & n.a. & $\begin{array}{l}\text { Calc.-alk. } \\
\text { volcaniclastic }\end{array}$ & 83 & $620-1050$ & $107.4 \pm 1.2$ & $106.7 \pm 1.2$ & $320.8 \pm 36.7$ \\
\hline
\end{tabular}

'Type' refers to spectra 'morphology' type (see text). Sample localities are shown in Figures 1 and 9. NO, Northland ophiolite; MA, Miocene arc; CA, Cretaceous arc. n.a., not applicable.

*Samples that fully satisfy the minima criteria needed for acceptance of a ${ }^{40} \mathrm{Ar} /{ }^{39} \mathrm{Ar}$ age derived from a step-heating experiment (Lanphere \& Dalrymple 1978 ).

mediate temperature steps $\left(900-1000{ }^{\circ} \mathrm{C}\right)$ with the release of between 80 and $95 \%{ }^{39} \mathrm{Ar}$ for a given plateau (Fig. 6a). Two of three samples yield plateau ages that are concordant with their (reverse) isochron ages. The plateaux extend from the earliest step (temperature typically below $600{ }^{\circ} \mathrm{C}$ ) to intermediate temperature steps (maximum $1000^{\circ} \mathrm{C}$ ). After carefully correlating the $\mathrm{Ca} / \mathrm{K}$ and $\mathrm{Cl} / \mathrm{K}$ values for these plateau steps with the chemical compositions of phases present in the samples, we conclude that the gas composition of these plateau steps reflects the outgassing of glass at low temperatures, followed by that coming from groundmass plagioclase and clinopyroxene. Thus, the obtained plateau ages should be considered as crystallization (or eruption) ages. The anomalously old ages obtained at the highest temperature steps possibly reflect degassing of phenocryst assemblages, which possess inherited argon. The plateau ages are $26.1 \pm 1.0,26.2 \pm 0.6$, and $25.1 \pm 1.2 \mathrm{Ma}$ for the tholeiitic basalts and $25.0 \pm 0.8 \mathrm{Ma}$ for the alkalic basalt sample.

Type 2 age spectrum morphology. The age spectrum of Type 2 samples is similar to that of Type 1 apart from abnormally old ages appearing in the lowest temperature steps (Fig. 6b). Petrographic evidence shows that the Type 2 samples possess varying degrees of alteration (palagonite after glass, uralite after clinopyroxene, minor alteration of plagioclase to chlorite and epidote, and chloritization of microcrystalline groundmass assemblages), which is typically found in hydrothermally altered volcanic rocks. Nevertheless, they yield the most robust apparent ages, satisfying all four minimum criteria required for the acceptance of a ${ }^{40} \mathrm{Ar} /{ }^{39} \mathrm{Ar}$ plateau age (Lanphere \& Dalrymple 1978). The plateau ages for this group $(28.3 \pm 3.4,28.8 \pm 0.5,29.3 \pm 0.7$ and $29.6 \pm 1.0 \mathrm{Ma}$ ) are also concordant with the ${ }^{206} \mathrm{~Pb} /{ }^{238} \mathrm{U}$ age of $28.3 \pm 0.2 \mathrm{Ma}$ for zircons separated from the plagiogranite. Plateaux exist between low temperatures $\left(450-500{ }^{\circ} \mathrm{C}\right)$ and high temperatures $\left(1020-1150{ }^{\circ} \mathrm{C}\right)$ with the release of between 74 and $88 \%{ }^{39} \mathrm{Ar}$ for a given plateau. The discordant (old) ages obtained in the earliest and latest steps of the experiments are presumably due to excess argon; the spectra probably represent the product of hydrous phases (i.e. deuteric or secondary chlorite) outgassing at low temperatures and the outgassing of altered phenocrysts at high temperatures, which are similar to those described by Lo et al. (1994) for altered samples of volcanic rocks of the Luzon arc near Taiwan. Because of the instability (i.e. low retentiveness) of alteration phases even at low temperatures, excess argon $\left({ }^{40} \mathrm{Ar}_{\mathrm{E}}\right)$ is released, yielding discordant (old) ages in the low-temperature fraction of the spectra. For the high-temperature steps, excess argon held in low-intermediate temperature retentive sites (i.e. cores), is liberated, reflected in the discordant (old) ages at the high-temperature fraction of the spectra. At intermediate temperature steps, gas dominated by the outgassing of unaltered plagioclase represents the plateau. As discussed by Lo et al. (1994), in many cases the plateau age of an altered sample can still provide constraints for the age of eruption, as the possible effects of alteration may be reflected in age disturbances only at low- and high-temperature steps. Moreover, if the alteration reactions are hydrothermal the plateau ages can still be considered as the ages of volcanism, as such alteration often occurs concurrently with volcanism and the age difference may be smaller than the error of the age estimate.

\section{Interpretation of ${ }^{40} \mathrm{Ar} /{ }^{39} \mathrm{Ar}$ step-heating experiments}

Consensus on the age of generation for the Northland ophiolite has been elusive despite various radiometric studies employing $\mathrm{K}$-Ar dating on whole rocks and mineral separates (Brothers \& Delahoye 1982; Hopper \& Smith 1996). The large range and anomalously old ages (100-42 Ma) (obtained by Brothers \& Delahoye (1982)) compared with this study may be attributed to non-equilibration of the samples with atmospheric Ar, although this explanation is speculative because Brothers \& Delahoye did not provide ${ }^{40} \mathrm{Ar} /{ }^{36} \mathrm{Ar}$ ratios.

Conversely, Hopper \& Smith (1996) obtained K-Ar ages ranging from 25 to $15 \mathrm{Ma}$ on mineral separates of plagioclase and hornblende from gabbro and sheeted intrusive rocks at North Cape. They attributed the younger ages to argon loss. However, the older ages (i.e. c. $25 \mathrm{Ma}$ ) are not significantly different from the average age of $c .28 \mathrm{Ma}$ for the tholeiitic basalts in this study.

As shown in Tables 2 and 3, eight of the nine ophiolite basalt samples range from $29.6 \pm 1.0 \mathrm{Ma}$ to $25.1 \pm 1.2 \mathrm{Ma}$ (the age of one sample of $18.7 \pm 0.3 \mathrm{Ma}$ is interpreted to represent a sample from the Miocene arc complex, a conclusion that is supported by its chemical characteristics). The ophiolite alkalic basalt sample 

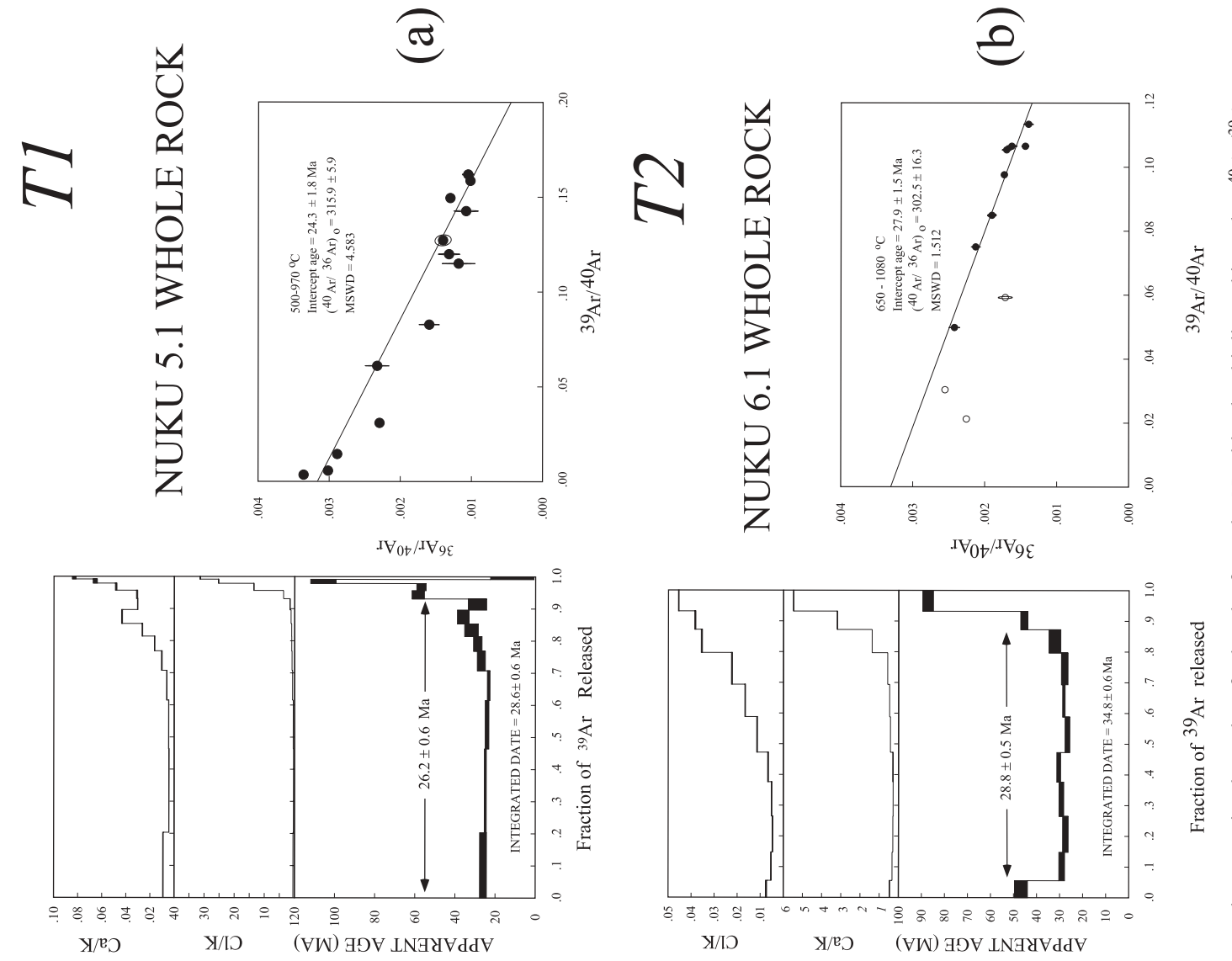

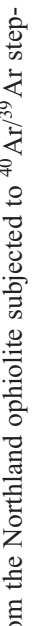

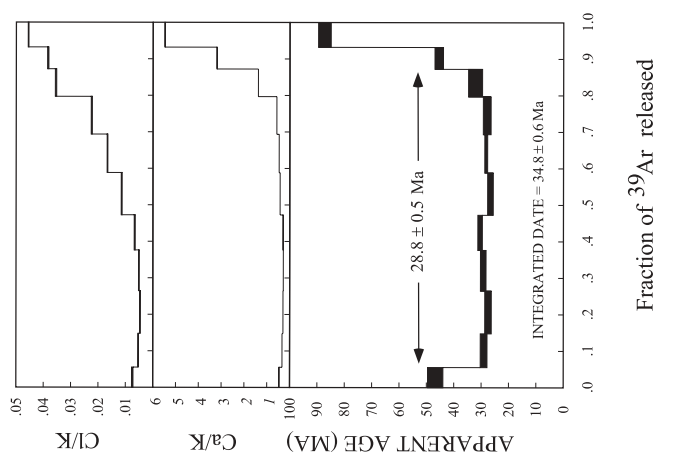

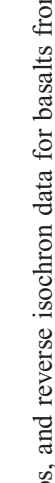
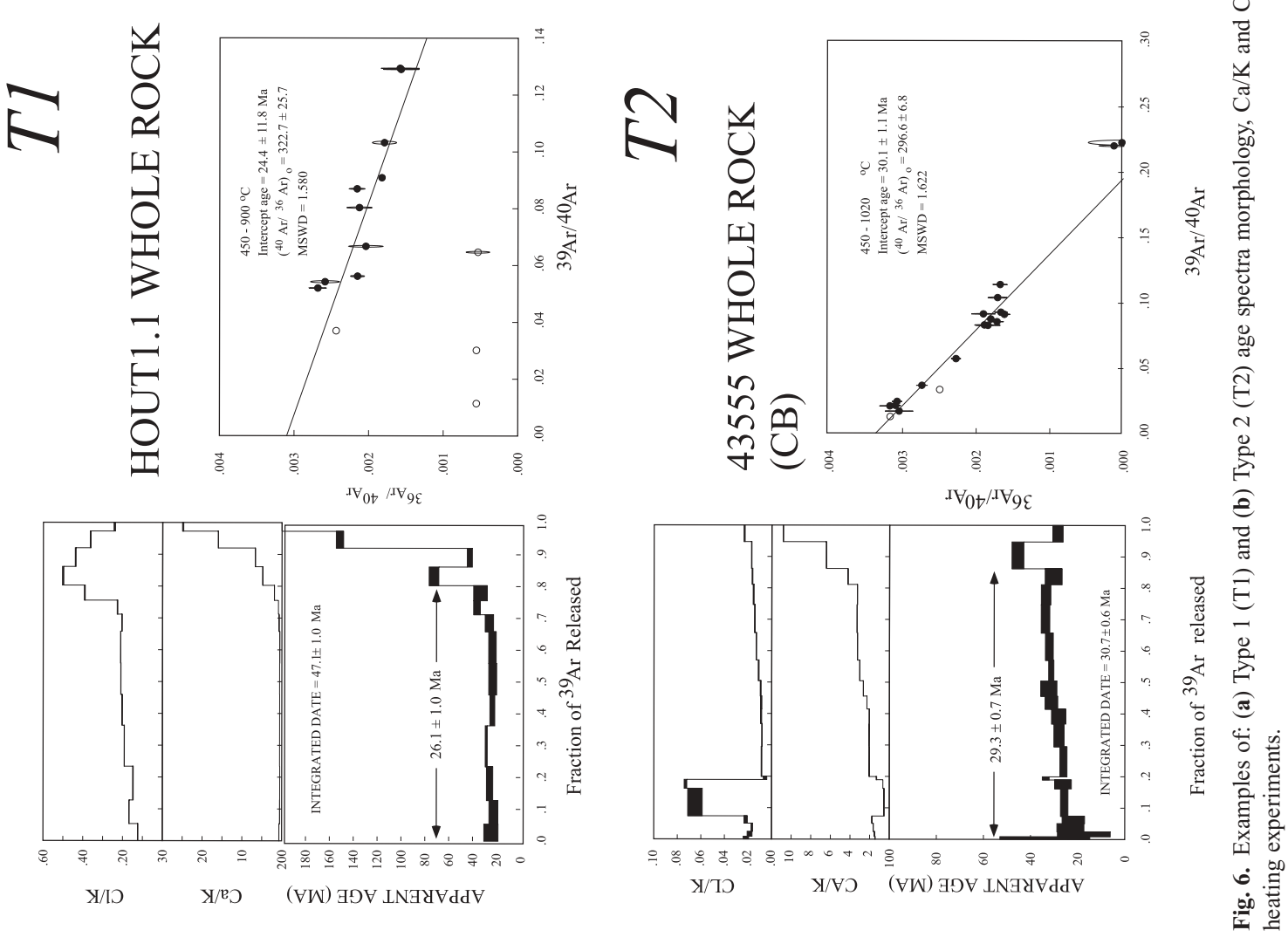
Table 3. Data for all dating methods employed on geological material from the Northland ophiolite (Whattam et al. 2003)

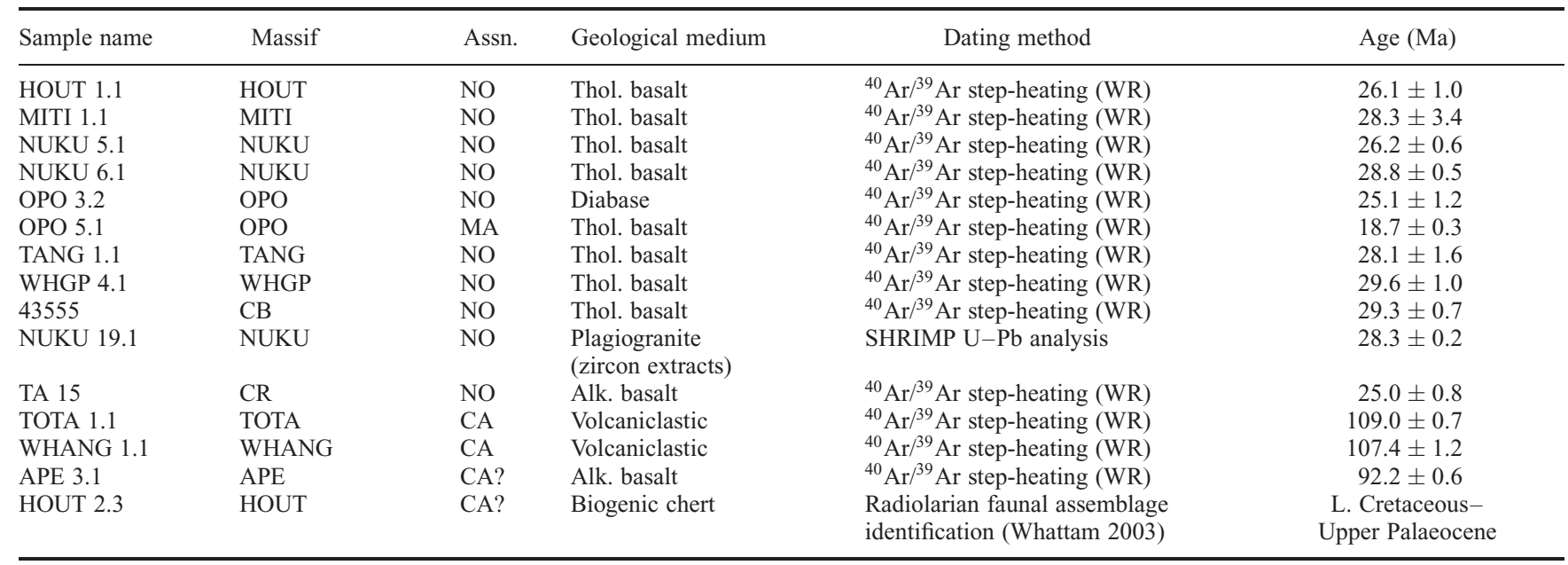

NO, Northland ophiolite; MA, Miocene arc; CA, Cretaceous arc; WR, whole rock. All ${ }^{40} \mathrm{Ar} /{ }^{39} \mathrm{Ar}$ dates are plateau ages. Sample localities are shown in Figures 1 and 9 and massif abbreviations are given in Figure 1.

yields an age of $25.0 \pm 0.8 \mathrm{Ma}$. The older (c. $108 \mathrm{Ma}$ ) ages obtained from three volcaniclastic samples are probably attributable to them being fragments of the genetically unrelated Cretaceous arc (i.e. the Houhora Complex, and derivatives thereof). The distribution and location of massifs from which samples were dated are shown in Figure 7.

\section{Palaeomagnetism and the formation latitude of the Northland ophiolite}

Palaeomagnetic data can potentially be used to deduce where the Northland ophiolite formed. Cassidy (1993) reported the only palaeomagnetic study so far carried out on Northland ophiolite rocks, presenting data from the Cape Reinga Massif, at the tip of the Northland Peninsula (six sites), and the Mangakahia Massif, $160 \mathrm{~km}$ to the SE (also six sites). As with many palaeomagnetic studies of ophiolitic material, the data obtained were somewhat variable, with only a limited number of sites yielding reliable results (five of the 12 sites of Van der Voo (1990) criteria are used as a guide; see Ali \& Aitchison 2000). Perhaps Cassidy's most important conclusion, based on a subset of data, was that the Northland ophiolite formed at about $15-20^{\circ} \mathrm{S}$, a considerable distance north of its present-day position, and even further from its late Oligocene obduction site $\left(c .38^{\circ} \mathrm{S}\right.$ based on the modelling of Schettino \& Scotese (2001)). However, movement of the ophiolite so far south before obduction is unlikely (Ali \& Aitchison 2000) because the regional sectors of the major adjacent plates, i.e. Pacific and Indo-Australian, both had considerable absolute northward motion components throughout the Palaeogene.

\section{Palaeomagnetic methods}

Core specimens of $25 \mathrm{~mm}$ diameter were obtained using a gasolinepowered rock-drill. The cores were oriented using a Brunton magnetic compass-inclinometer mounted on a Pomeroy orientation table. Generally six or seven mini-cores were collected from each site, although at some pillow lava sites it was only possible to collect three or four samples because of drilling-induced fracturing of the cores. The structural attitude was measured at each site to provide a tilt correction. Stability of the natural remanent magnetization (NRM) of each specimen was assessed after stepwise alternating field (AF) demagnetization was used to isolate the various magnetic components. The specimens were processed using a JR5A spinner magnetometer and demagnetized using a Molspin tumbler demagnetizer. Vector-end-point diagrams (Zijderveld 1967) were used to analyse the data from each sample (representative plots are shown in Fig. 8). In most cases, principal component analysis (Kirschvink 1980) was used to determine characteristic remanent magnetization (ChRM) directions for each specimen, although in a number of instances the statistics of Fisher (1953) were applied to several different demagnetization-step directions. Fisher statistics were also used to calculate site mean directions (Fig. 9 and Table 4).

\section{Masters' Quarry, Ahipara (Ahipara Massif)}

Seven sites were sampled in a 50-60 m thick succession of subhorizontally dipping pillow lavas exposed in Masters' Quarry, $5 \mathrm{~km}$ from Ahipara (Fig. 1). An eighth site was also sampled in a $4.5 \mathrm{~m}$ wide diabase dyke at the western end of the quarry. Three pillow lava sites yielded data with westerly declinations (c. $\left.264^{\circ}\right)$ and moderately inclined positive inclinations $\left(c .40^{\circ}\right)$ (see Table 4). These directions are interpreted to record a reverse polarity remanence, which has experienced considerable clockwise rotation. In contrast, the dyke (NO8) has a northerly $\left(4.9^{\circ}\right)$ steep upward-directed remanence $\left(-73.4^{\circ}\right)$, indicating a negligibly rotated normal-polarity magnetization. The pillow-dyke directional difference strongly suggests that remanence is primary, but the apparent lack of antipodality suggests that the two units are of different ages. Geochemically, however, they are identical, suggesting that they are magnetically coeval, the dyke being a 'feeder' for the pillows. It is therefore likely that Site NO8 records a substantial offset in the time-averaged direction of the geomagnetic field when the dyke was emplaced.

\section{Tauroa Point, west of Ahipara (Ahipara Massif)}

Four sites were sampled from a series of $c$. metre-wide subvertical NW-trending basaltic dykes exposed along a halfkilometre stretch of the shore close to Tauroa Point, west of Ahipara (Fig. 1). None of the sites, some of which included samples from the immediately adjacent country rock pillow 


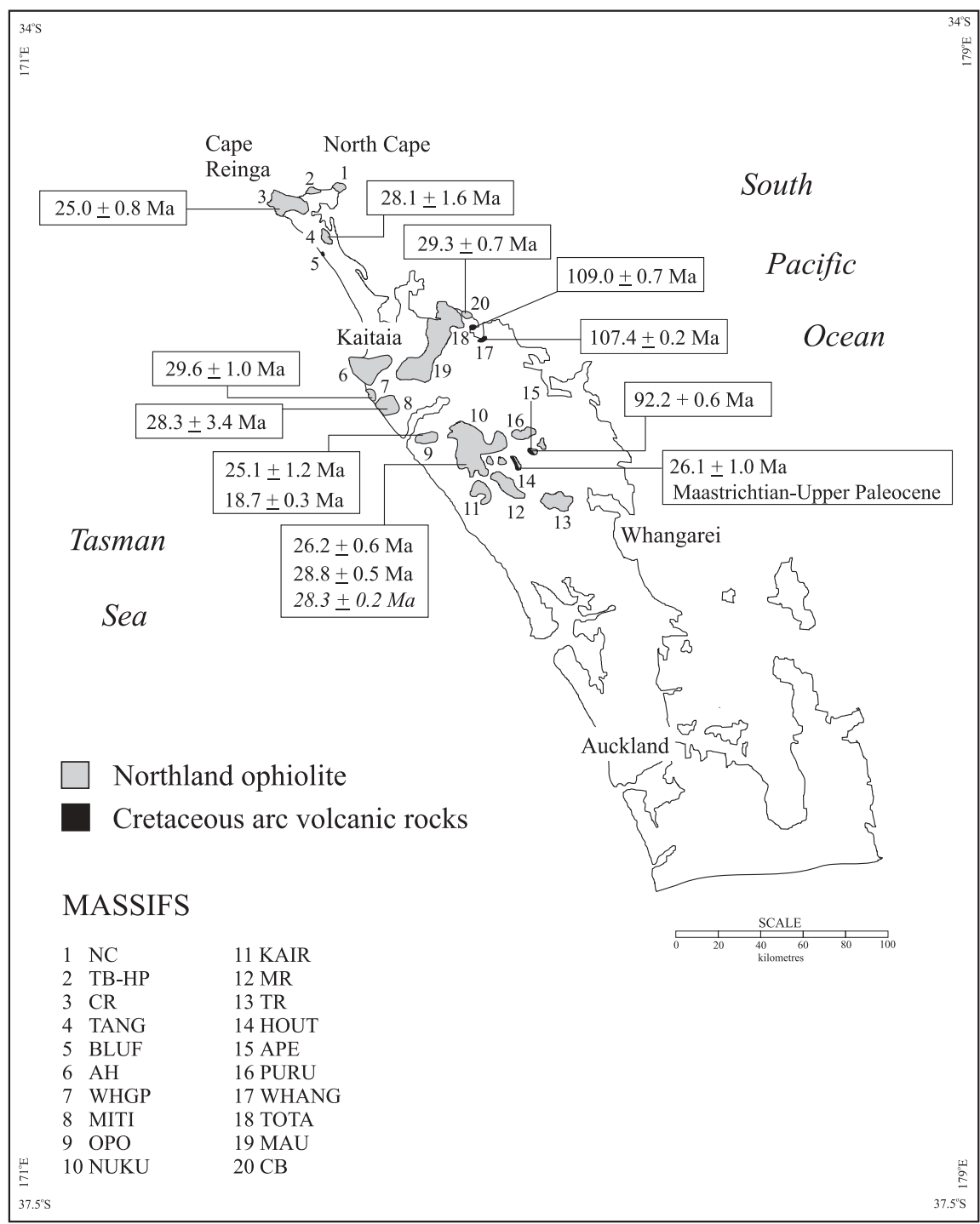

Fig. 7. Sketch of Northland showing the localities and ages obtained from the various dating campaigns. (See Tables 2 and 3 for more details.) The date in italics represents the SHRIMP $\mathrm{U}-\mathrm{Pb}$ age obtained on zircons from plagiogranite sample NUKU 19.1. Abbreviations are as in Figure 1.
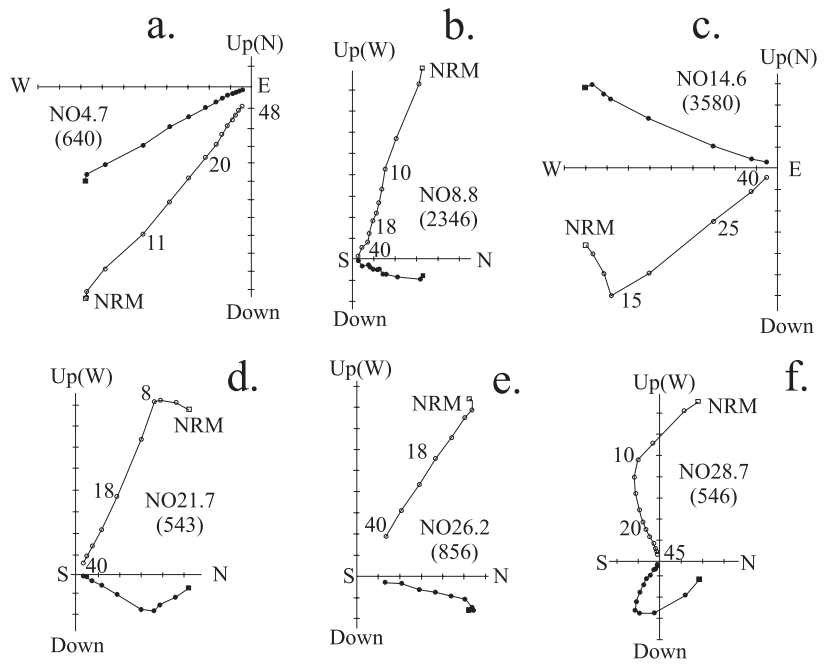

Fig. 8. Vector-end-point plots (Zijderveld 1967) showing examples of AF demagnetization data, in tilt-corrected coordinates, for Northland ophiolite specimens. (a) NO4.7 (pillow basalts) and (b) NO8.8 (diabase dyke) from Masters' Quarry; (c) NO14.6 basaltic sill, eastern Cooper's Beach; (d) NO21.7 pillow basalt site at northern end of 90-Mile Beach; (e) NO26.2 pillow basalt site at Cable Bay; (f) NO28.7 site in a diabase dyke at the western end of Cooper's Beach. The numbers indicate the AF demagnetization step in mT. Initial NRM intensities $\left(J_{\mathrm{o}}\right)$ are shown below the specimen name (units of $\mathrm{mA} \mathrm{m}^{-1}$ ). 

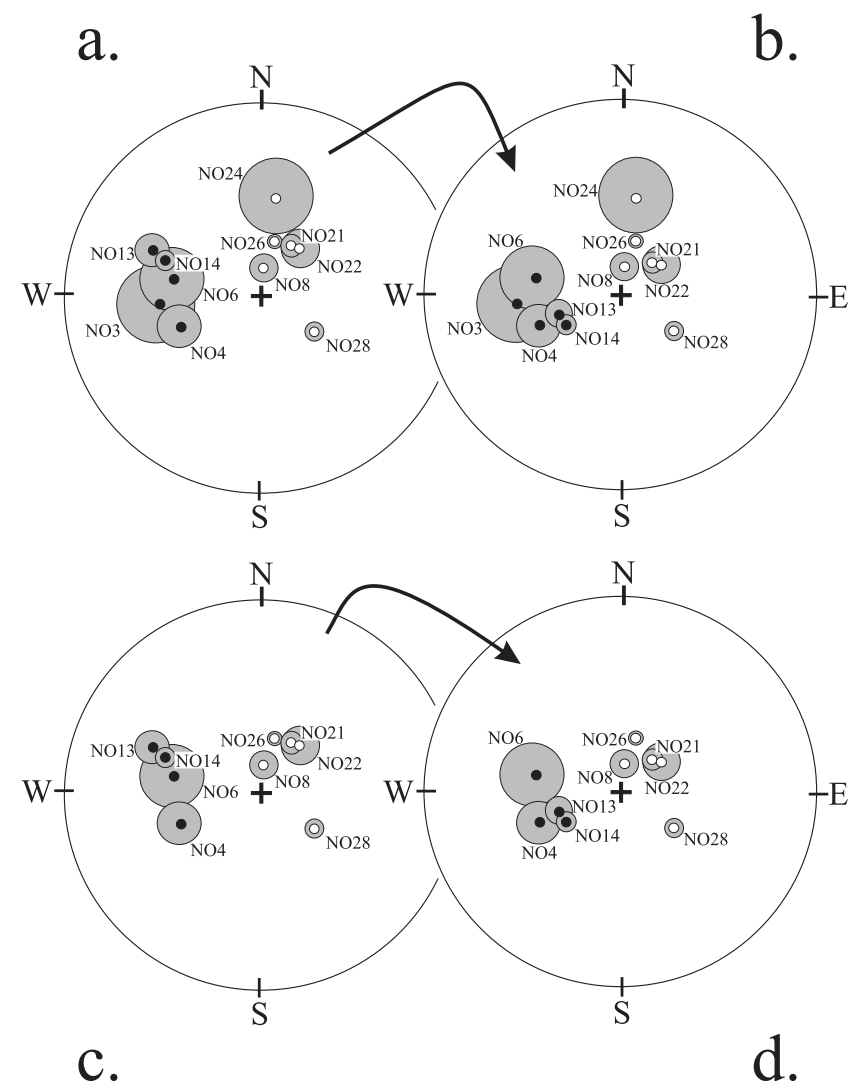

Fig. 9. Summary of palaeomagnetic directional data. Upper plots are for all Class 1 and 2 sites: (a) in situ; (b) tilt corrected. Lower plots are for all Class 1 data: (c) in situ; (d) tilt corrected; sites NO3 and NO24 have been removed. Filled and open symbols are downward and upward directed, respectively. The site mean directions are shown with their $95 \%$ confidence circles (equal angle stereographic projection).

lavas, yielded useful data (Table 4). The magnetization in these rocks is dominated by a randomly oriented low-coercivity remanence, which probably records a laboratory storage field.

\section{Cooper's Beach (Maungataniwha Massif)}

The Northland ophiolite crops out at headlands to the east and west of Cooper's Beach on the eastern Northland Peninsula (Fig. 1). Two sites were sampled from the eastern headland, where a pillow lava sequence intruded by a sill of $2.5 \mathrm{~m}$ thickness is exposed (dip is $48^{\circ}$ towards the SE). The two sites (NO13-4) yielded similar directions (Table 4), which in tilt-corrected coordinates have a mean of direction of declination $(D)$ of $247.0^{\circ}$, and inclination $(I)$ of $54.2^{\circ}$, where the angular separation is $7.1^{\circ}$ (the two sites are sufficiently far apart $(4 \mathrm{~m})$, for complete thermal resetting of the pillows not to have taken place, which might have led to the two sites carrying identical directions). At the western end of Cooper's Beach (c. $2 \mathrm{~km}$ away from Sites NO13-4), a single site (NO28) was sampled in a diabase dyke of $3 \mathrm{~m}$ width, which yielded a mean direction of $D=123.8^{\circ}$, $I=-53.6^{\circ}$ (Table 4). Interestingly, the inclinations of the two Cooper's Beach outcrops are, in absolute terms, identical (and of opposite polarity). The declinations suggest large-scale clockwise rotation of the two outcrops, although the clearly more rotated eastern section $\left(>120^{\circ}\right)$ indicates that the two are separated by a tectonic boundary.

\section{Cable Bay (Maungataniwha Massif)}

Two sites were sampled from Northland ophiolite pillow lavas at the eastern end of Cable Bay (which lies just to the east of Cooper's Beach) (Fig. 1). One site (NO25) yielded useful data, although its mean direction $\left(D=14.6^{\circ}, I=-58.0^{\circ}\right)$ is based on just three of the five samples processed from this site (Table 4). Site NO26 yielded a broadly similar direction $\left(D=19.7^{\circ}\right.$, $\left.I=-37.0^{\circ}\right)$, but the associated $\alpha_{95}$ and $k$ values $\left(30.0^{\circ}, 10.4\right)$ suggest that the data should not be used for tectonic modelling.

\section{Bellingham's Quarry, south of Kaitaia (Ahipara Massif)}

Two sites were sampled in pillow lavas and sheet flows in Bellingham's Quarry, just to the south of Kaitaia (Fig. 1). Site NO15 yielded data (tilt-corrected $D$ and $I$ of $340.4^{\circ}$ and $50.3^{\circ}$ ), but the $\alpha_{95}\left(22.1^{\circ}\right)$ and $k$ (18.2) values (Table 4) indicate relatively poor clustering of the directions and, based on Van der Voo (1990), the direction should be excluded from any tectonic interpretation.

\section{Northern end of 90-Mile Beach (Cape Reinga Massif)}

The northern end of 90-Mile Beach (Fig. 1) is marked by steep cliffs and rugged terrain developed in Northland ophiolite rocks. Two sites each were sampled in the pillow lavas (NO21-2) and presumed feeder dykes (NO23-4). The two pillow lava sites yielded northeasterly declinations with inclinations in excess of $-60^{\circ}$ (Table 4), indicating a normal-polarity magnetization rotated through about $50^{\circ}$. Again this contrasts with the (feeder) dyke Site NO24, which yielded a negligibly rotated declination and a somewhat shallow inclination $\left(-36.5^{\circ}\right)$, although as at Bellingham's Quarry, the $\alpha_{95}$ and $k$ values $\left(17.2^{\circ}, 20.8\right)$ are 'marginal'.

\section{Te Paki Station, near Cape Reinga (Cape Reinga Massif)}

One site sampled in the sheet flows exposed in a small quarry at Te Paki Station (Fig. 1) failed to yield any useful palaeomagnetic data (Table 4).

\section{Palaeomagnetic summary and interpretation}

As can be seen from the preceding section (as well as the $\alpha_{95}$ and $k$ values listed in Table 4 ), the obtained directions are of variable quality, thus to calculate the latitude at which the Northland ophiolite rocks formed at it has been necessary to screen the data. The site-mean directions were allocated to one of three classes (Class 1 being good, Class 3 being dubious) based on the clustering statistics and the suggestions of Van der Voo (1990). Nine sites belong to Class $1\left(\alpha_{95} \leqslant 15.3^{\circ}\right)$ and two sites (with $\alpha_{95}>20^{\circ}$ ) are assigned to Class 3. Two sites that sit close to the cut-off limit of Van der Voo (1990), NO3 and NO24, are assigned to Class 2 (Fig. 9a and b). In all cases, the tiltcorrected mean inclinations, using the statistics of McFadden \& Reid (1982), yield slightly better $\alpha_{95}$ and $k$ values than the directions in geographical coordinates (Table 4), although it must be recognized that in only two exposures are the dips greater than $25^{\circ}$ and in many outcrops the rocks are flat-lying, thus this attitude test is limited.

The mean inclination of the Class 1 sites gives a formation 
S. A. WHATTAM $E T A L$.

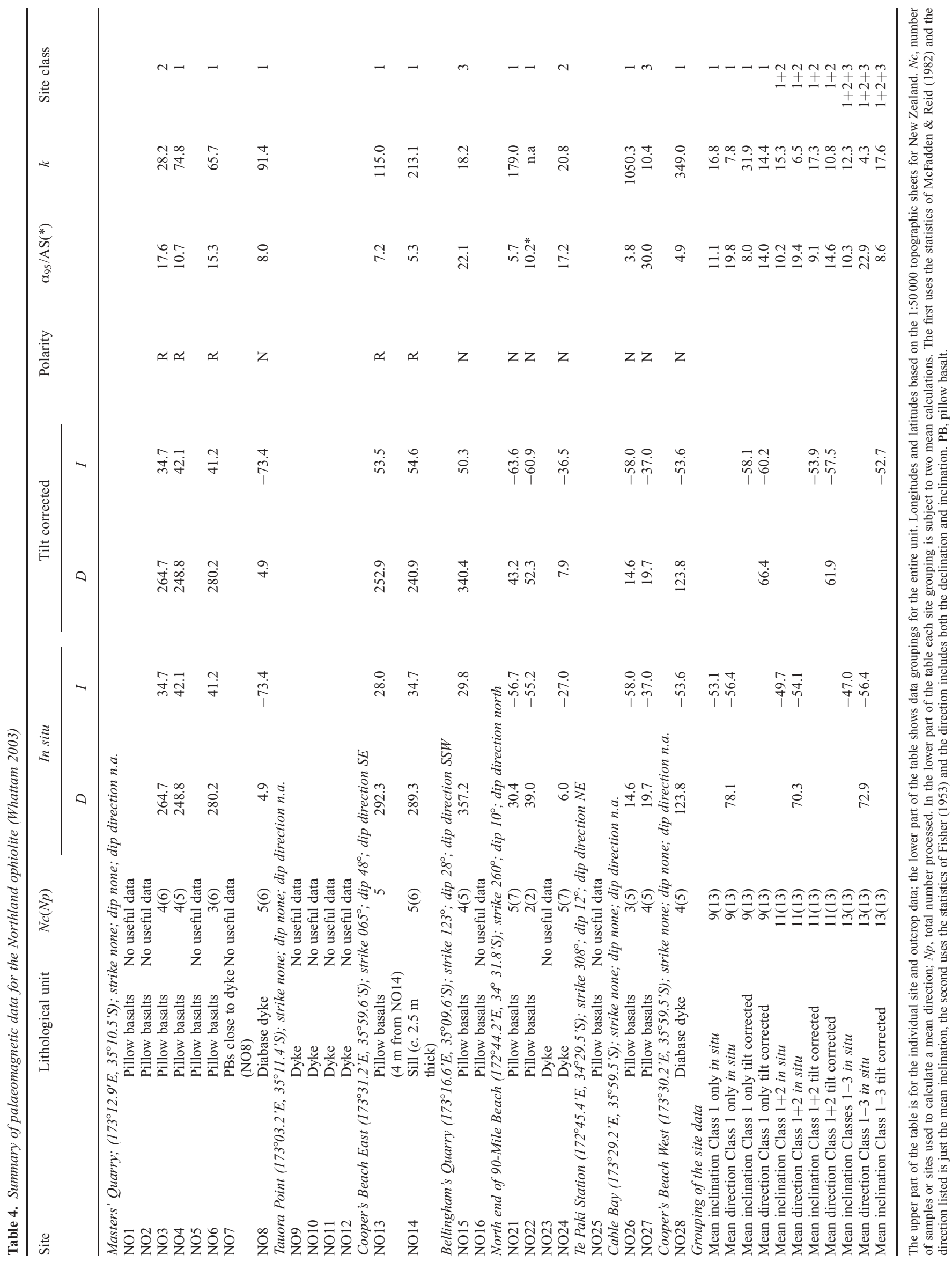


palaeolatitude of $38.8 \pm 10.6^{\circ} \mathrm{S}$, whereas the mean of the Class 1 and 2 sites gives a slightly lower value of $34.4 \pm 9.0^{\circ} \mathrm{S}$. Critically, however, both values place the formation site of the Northland ophiolite close to its $c .38^{\circ} \mathrm{S}$ obduction site (see Fig. $10)$, acknowledging the non-negligible associated error $\left(c .10^{\circ}\right)$. Two other points to emerge from the plots in Figure 9 are: (1) the Class 1 and/or Class 2 data display a visibly better clustering in tilt-corrected rather than in situ coordinates (see Table 4); (2) the majority of sites appear to record a large clockwise rotation $\left(>60^{\circ}\right)$. With regard to point (1), however, the respective 'cluster' statistics of the nine Class 1 sites $\left(D=78.1^{\circ}, I=-56.4^{\circ}\right.$, $\alpha 95=19.8^{\circ}$ and $k=7.8$ for the in situ direction versus $D=66.4^{\circ}, I=-60.2^{\circ}$, a95 $=14.0^{\circ}$ and $k=14.4$ for the tiltcorrected direction) indicate that this apparent grouping should be treated with some caution. With regard to (2), first it is necessary to subtract $7-8^{\circ}$ from the clockwise declination offset to account for the Neogene motion of the Australian Plate relative to the geographical spin axis (based on the palaeomagnetic pole compilation of Acton \& Kettles (1996)). Second, the apparent consistency in declination offsets is somewhat unexpected as the massifs are klippen and in such a situation local vertical-axis rotations would probably have taken place between bodies during emplacement, thereby scattering the declinations (it should be noted that local rotations are recorded by the Cooper's Beach sites). Acknowledging the limitations in the dataset, it is postulated that the Northland ophiolite was emplaced as a single body, and that the physical 'gaps' between massifs are due to post-emplacement erosion.

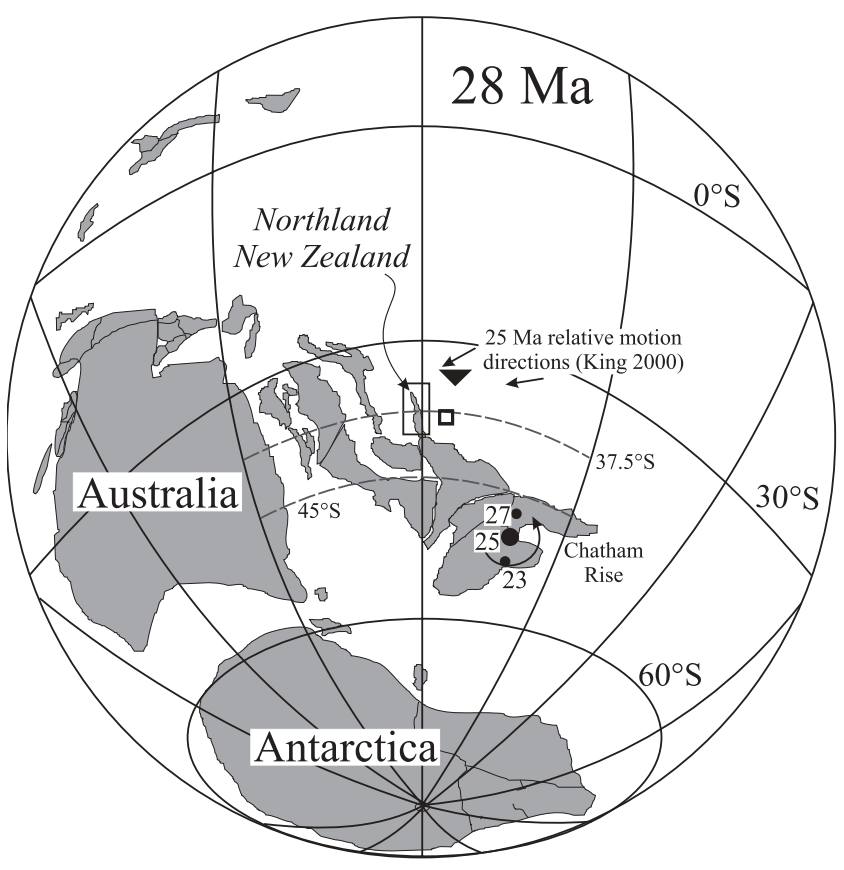

Fig. 10. Plate reconstruction for the SW Pacific at $28 \mathrm{Ma}$, based on Schettino \& Scotese (2001), with minor modifications following Little \& Roberts (1997) (for the eastern North Island immediately to the north of Chatham Rise). The generation latitude of the Northland ophiolite is shown with the small open square (mean inclination of the Class 1 sites) and inverted filled triangle (mean inclination of the Class 1 and 2 sites); the associated errors of both values are $c .9^{\circ}$. Also shown are the PacificAustralia instantaneous rotation poles for 27, 25 and $23 \mathrm{Ma}$ (from King 2000, following Sutherland 1995), and the approximate motion directions (for $25 \mathrm{Ma}$ ) of the Pacific Plate relative to the Australian Plate in the area to the east and NE of Northland, as well that about the rotation pole.

\section{Plate tectonic interpretation}

The possibility that the Northland ophiolite formed close to its obduction site at c. $38^{\circ} \mathrm{S}$ (Fig. 10) makes generating a tectonic model somewhat more straightforward than with the earlier published data of Cassidy (1993), which implied that the ophiolite formed at $15-20^{\circ} \mathrm{S}$, a considerable distance north of its obduction site. Along with the new geochemical and radiometric age-dating data, it is suggested that the ophiolite was generated in the South Fiji Basin. If this idea is correct then it is first necessary to develop a tectonic model that can account for the unit's emplacement and also accommodate other geological knowledge for the region during the Oligocene and Miocene. Factors to consider include: (1) the period over which the South Fiji Basin formed and its tectonic relationship with northern New Zealand; (2) conspicuous changes in plate motion, particularly for the major plates, Australia and the Pacific; (3) the time of emplacement of the ophiolite; (4) any relevant structural data; (5) the initiation and development of the Northland arc.

Magnetic surveys of Watts et al. (1977) and Davey (1982) in the South Fiji Basin identified anomaly lineations 12-7A; Malahoff et al. (1982) suggested that anomaly 13 is locally present. This suggests, using the Cande \& Kent (1995) magnetic polarity time scale, that spreading started at around $33 \mathrm{Ma}$, and possibly $36 \mathrm{Ma}$, and that it continued to $c$. $25.5 \mathrm{Ma}$. During formation, the South Fiji Basin adjacent to northern New Zealand had a NE-SW-oriented spreading centre. At present, an extinct transform, the Vening Meinesz Fracture Zone (Van der Lingen 1967) separates the South Fiji Basin from northern New Zealand but, as will be explained below, we suggest that another transform, located to the SW of the Vening Meinesz Fracture Zone, may have been the original plate boundary.

Temporally, the Northland ophiolite's emplacement corresponds closely to a change in relative motion of the IndoAustralian and Pacific Plates (Yan \& Kroenke 1993). Work in eastern Indonesia and Papua New Guinea indicates that in the early Miocene the Australian continental plate in New Guinea collided with an extensive intra-oceanic arc that had formed during the late Eocene-Oligocene on the southern edge of the Philippine Sea Plate (Ali \& Hall 1995; see also Hall 2002). At about the same time the Hikurangi Plateau, a submerged $3.5 \times 10^{5} \mathrm{~km}^{2}$ Cretaceous large igneous province immediately to the NE of Chatham Rise, appears to have collided with western New Zealand. Mortimer \& Parkinson (1996) argued that the coeval emplacement of the Northland and East Cape allochthons in the Late Oligocene-Early Miocene may have been triggered by this event.

The plate motion modelling studies of Sutherland (1995) and the subregional reconstructions by King (2000) indicate that the rotation pole between the Australian and Pacific Plates migrated steadily towards $c .150^{\circ} \mathrm{E}$ during the late Eocene to Miocene, passing over the central part of the Chatham Rise in the late Oligocene-earliest Miocene (Fig. 10). With regard to northern New Zealand, the basic effect was to gradually increase the convergence rate between the two main plates. Throughout this time, the convergence direction remained roughly west- to SWdirected but marginal basin growth in the Australian Plate to the east of the North Island (i.e. South Fiji Basin in the Oligocene, Havre Trough during the Plio-Pleistocene) renders this locally more complex over specific time intervals.

A fourth consideration is the direction in which the Northland allochthon was thrust over the basement of northern New Zealand; Rait et al. (1991) and Rait (2000) have clearly shown from detailed structural work that the unit was emplaced from 
the NE $\left(40 \pm 10^{\circ}\right)$. As such, the compiled data are entirely compatible with the modelling of Sutherland (1995) and King (2000). A final important piece of information concerns the Northland arc, which developed along the length of the northern North Island in the early and mid-Miocene (Ruddock \& Spörli 1989; Smith et al. 1989; Hayward et al. 2001). The basic geometry of the preserved arc suggests that the oceanic lithosphere consumed beneath Northland was at a trench that was aligned approximately NNW-SSE.

The tectonic scenario that is presented below and in Figure 11 accommodates all of the above events, phases and features that are keys to the region's Oligo-Miocene development. In the period 33-26 Ma (Fig. 11a), we envisage spreading at the southwestern end of the South Fiji Basin to have been on either side of a NE-SW-oriented ridge. The basin would have formed in a back-arc setting above the subducting Pacific Plate (a useful modern-day analogue being the nearby Havre Trough-Pacific Plate subduction system). To decouple the spreading basin from northern New Zealand, they must have been separated by a transform fault. As previously mentioned, the current 'boundary' between northern New Zealand and the South Fiji Basin is the Vening Meinesz Fracture Zone. However, for reasons that will be explained in the obduction phase description, we deduce that the original boundary was another transform that paralleled and lay to the SW of the Vening Meinesz Fracture Zone, the evidence for which may be preserved at Camp Bay (Hanson 1991), and possibly at the eastern headland of Cable Bay (Whattam, personal observations). Hereafter, we refer to this transform as the Camp Bay Transform.

At around $25 \mathrm{Ma}$ the Hikurangi Plateau on the Pacific Plate was brought up against northern New Zealand. Although this collision would have been 'soft' (the plateau at this time would have been very close to the Australia-Pacific Plate instantaneous rotation pole), it may have caused regional disruption, particularly spreading in the South Fiji Basin and at other important tectonic boundaries in the region, for example, the Camp Bay Transform (Fig. 11b). Indeed, with a general WSW-SW-directed plate convergence direction in the area to the NE of Northland (e.g. King 2000), it may then have been possible to ramp-up the upper-crustal portion of the southern South Fiji Basin onto the continental margin of New Zealand at the Camp Bay Transform (the envisaged 'flaking' mechanism being not too dissimilar to that of Oxburgh (1972) and more specifically to Model 2 of Malpas et al. (1992)). Shortly after this plate reorganization, subduction of the lower-crustal portion and mantle initially, and a full lithospheric section soon after, may have led to the generation of the Northland arc. The tectonic model would also account for the generation of the Three Kings Ridge (as an arc) to the north of Northland.

\section{Other considerations}

The available biostratigraphic data from inter-pillow sediment in the ophiolite span the Late Cretaceous to Palaeocene (Farnell 1973; Brothers \& Delahoye 1982; Brook et al. 1988; Larsen \& Spörli 1989), which contrasts with the obtained late Oligocene radiometric ages. This disparity between the two data sources can be explained in one of three ways: (1) the radiolaria belong to Cretaceous arc-related rocks that were mistakenly identified as ophiolite; (2) the radiolarians belong to unrecognized 'other' basement terrane (i.e. basement excluding the Permian-Jurassic Torlesse Supergroup metagreywacke); (3) there are at least two ophiolites.

In the first scenario, the Late Cretaceous-Palaeocene fossils come from the Cretaceous arc $\left({ }^{40} \mathrm{Ar} /{ }^{39} \mathrm{Ar}\right.$ ages of $92.2 \pm 0.6$, $107.4 \pm 1.2$ and $109 \pm 0.7 \mathrm{Ma}$ ), which has been mistakenly identified as part of the Northland ophiolite. As the lithologies are not significantly different from the Oligocene Northland ophiolite rocks and exposure is not always perfect, some massifs could include rocks of both ages. For example, at the Houto massif (massif 14, Figs 1 and 7) Maastrichian-Palaeocene radiolaria were recovered from sediments intercalated with pillow basalt (Whattam 2003) and a ${ }^{40} \mathrm{Ar} /{ }^{39} \mathrm{Ar}$ age for a tholeiitic basalt from the same massif records an Oligocene age (Tables 2 and 3). The Houto massif is known to contain alkalic rocks (Hughes 1966); as the ophiolite complex and the Cretaceous arc complex both have alkalic suites, the radiometric age probably records the age of the Northland ophiolite, whereas the fossils possibly record the age of the older alkalic suite within which they are intercalated. Related to this, the alkalic basalt of the basal segment of the nearby Apenga massif (massif 15, Figs 1 and 8 ) yields a ${ }^{40} \mathrm{Ar} /{ }^{39} \mathrm{Ar}$ date of $92 \mathrm{Ma}$. This sample may be from a fragment of the Lower Cretaceous Houhora complex (Isaac et al. 1988), which is interpreted to be a parautochthonous or allochthonous sequence structurally underlying the Northland Allochthon. However, as sample HOUT 2.3 (chert) is in close proximity to radiometrically undated tholeiitic basalts (HOUT 2.1, 2.2 and 2.4), the fossils are more likely to be intercalated within rare tholeiitic basalts of the Mount Camel Terrane. As such, these tholeiitic basalts cannot be distinguished from the ophiolite basalts without radiometric dates.

A second plausible explanation is that the various fossilbearing basalts belong to the aforementioned basement terrane and/or to other distinct basement terranes. It is posible that the 'basement' of Northland (i.e. 'other basement', excluding the Permian-Jurassic Torlesse metagreywacke) consists of a collage of oceanic terranes that record deposition of fossils in submarine oceanic basins near offshore New Zealand. It is possible that these terranes were emplaced onto the Northland Peninsula at varying times between the Cretaceous and Oligocene before the ophioite was emplaced, or immediately preceding (effectively synchronous with) its emplacement.

A third plausible explanation is that there exist (at least) two imbricated ophiolites; a volumetrically dominant one of Oligocene and a subordinate one of Cretaceous age.

Finally, we comment on why the new palaeomagnetic dataset differs from that reported by Cassidy (1993). Essentially, the inclinations recorded in the earlier work appear to be anomalously low when compared with those obtained in the present study. The first possibility is that the tilt corrections applied to the 'old' dataset sites are incorrect (we note that only four of the 12 sites Cassidy sampled needed tilt correct to be applied). Second, the data analysis was inadequate; for example, the picking of the characteristic directions for individual specimens. A third possibility, which seems unlikely based on the new age-dating information presented herein, and the inherent problem of moving the allochthonous material south, is that Cassidy actually sampled the 'old' (Upper Cretaceous-lower Palaeogene) portions of the Northland ophiolite. Whatever the reason, the new data are more amenable to the development during the Palaeogene of a tectonic model that can also accommodate a variety of features we already know about northern New Zealand and the SW Pacific in the mid- and late Cenozoic.

\section{Conclusions}

Data from the Northland ophiolite suggest that it formed between 29 and $26 \mathrm{Ma}$ in a suprasubduction-zone environment at c. $35^{\circ} \mathrm{S}$ 

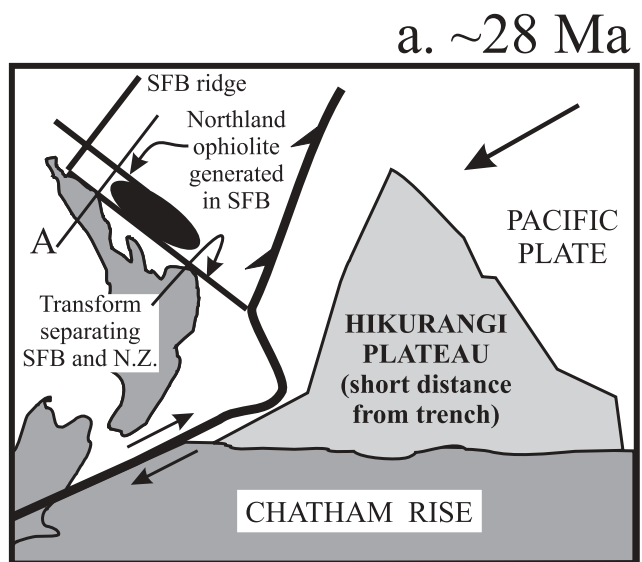

b. $\sim 25 \mathrm{Ma}$

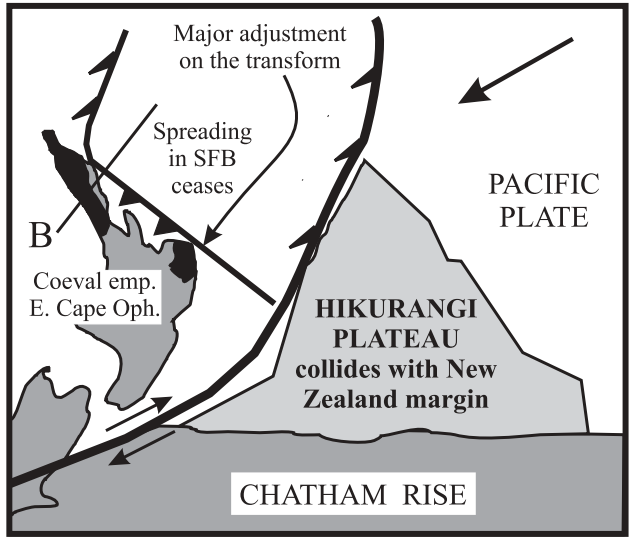

c. $\sim 21 \mathrm{Ma}$

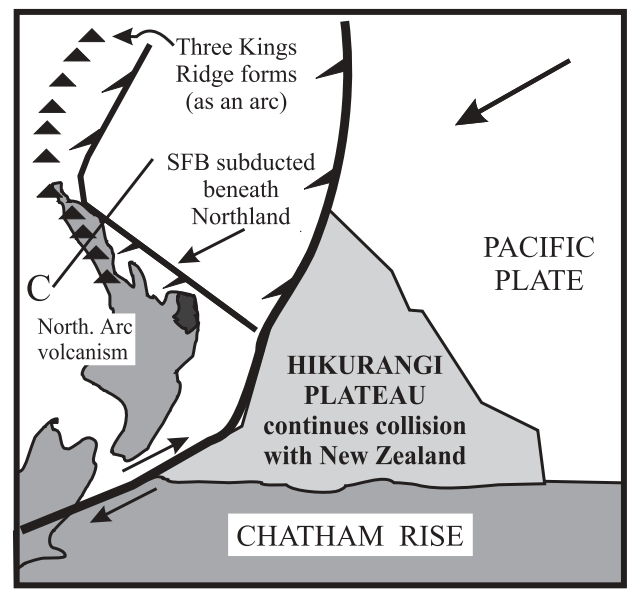

NE-SW cross-sections across Northland-SFB

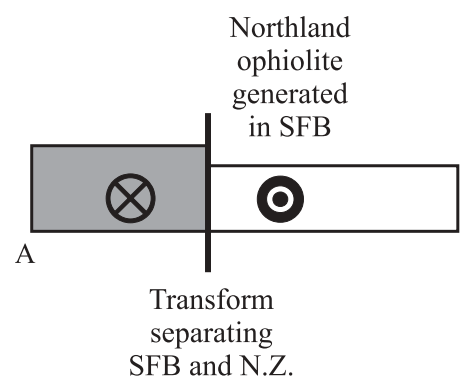

Northland ophiolite emplaced (from $\sim 040^{\circ}$ )

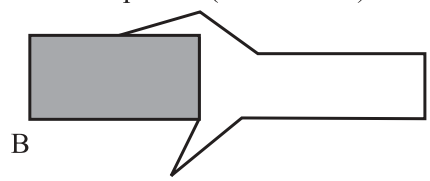

Early-middle Miocene subduction and generation of the Northland arc

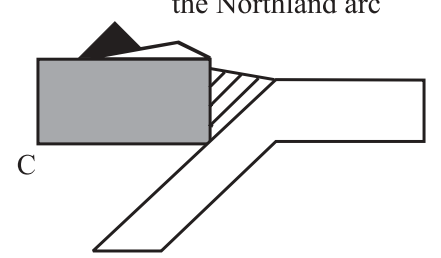

Fig. 11. Schematic illustration of the New Zealand region in the late Oligocene (a), terminal Oligocene (b) and early Miocene (c), showing the generation and proposed obduction model for the Northland ophiolite. In part, the model draws upon Rait et al. (1991), Yan \& Kroenke (1993), Sutherland (1995), Mortimer \& Parkinson (1996), King (2000) and Rait (2000). The large arrow in the NE corner of each map shows the approximate convergence direction of the Pacific Plate relative to Australia. The inferred sense of motion at different parts within the region is shown by the teeth on the subduction zones, and arrows and electrical current symbols next to the faults. In all diagrams, the eastern part of the North Island of New Zealand has been rotated counterclockwise to remove the affects of Pliocene-Recent extension in the Taupo Volcanic fieldHavre Trough. Additionally, northern New Zealand north of the plate boundary separating it from the Chatham RiseHikurangi Plate has been modelled using Little \& Roberts (1997). SFB, South Fiji Basin. and as such was probably generated in the southern South Fiji Basin, where a series of Oligocene magnetic anomalies (12-7A according to Watts et al. 1977; Davey 1982; 13-7A according to Malahoff et al. 1982) have been identified. Based on the time scale of Cande \& Kent (1995), these anomaly data suggest that the South Fiji Basin formed between 33.5 and 25.5 Ma.

We postulate that the ophiolite was emplaced following a major adjustment along a transform that separated the South Fiji
Basin and the northern New Zealand basement as a result of collision of the Hikurangi Plateau with the New Zealand margin at c. $25 \mathrm{Ma}$. The WSW-SW convergence direction the Pacific Plate was undergoing relative to Australia resulted in the upper crust of the South Fiji Basin being 'flaked' onto the basement of northern New Zealand, thereby resulting in the Northland ophiolite (it should be noted that only at North Cape (Fig. 1) is the lower portion of a classic ophiolite suite preserved, the 
sheeted dyke-gabbro-ultramafic sequence). However, most of the South Fiji Basin lithosphere driven against the Australian Plate was subducted, which then led to the development of the early to mid-Miocene Northland arc.

A model involving inception of the Kermadec-Colville arcridge, and by implication the establishment of strongly convergent subduction at the Pacific-Australia Plate boundary at $25 \mathrm{Ma}$ (and hence initiation of Miocene arc volcanism) is substantiated by microfossil and $\mathrm{K}-\mathrm{Ar}$ data for rocks from the Kermadec trench (Ballance et al. 1999). The widespread occurrence of Early Miocene arc volcanic rocks on Northland, and just to the west of the peninsula, is probably due to the highly oblique WSW-directed subduction of the South Fiji Basin. With this new model the Three Kings Ridge arc would have formed above the northern extension of this subduction-zone system (Fig. 11c).

Our model incorporates the conclusions of Rait et al. (1991) and Rait (2000), which dealt with the emplacement of the Northland allochthon, arc generation model and the early Miocene development of the Northland peninsula. The proposed scenario is also consistent with the regional tectonic works of Sutherland (1995) and King (2000).

This work was funded through HK CERG HKU 7017/03P grant to J.M. and an HKU CRCG award to J.R.A. We are grateful to N. Mortimer and G. Acton for sharing information and ideas, G. Thompson and J. Cassidy for their various insights, S. Zyabrev for his help in the identification of the radiolarian assemblages, A. Kennedy for his running of the SHRIMP at Curtin University, the Masters and Bellingham families for kind access to their quarries, and G. Chan for assistance in the field. Insightful comments from P. Ballance and T. Ireland greatly improved an earlier version of the manuscript, as did the formal reviews by A. Roberts and P. Cawood.

\section{References}

Acton, G.D. \& Kettles, W.A. 1996. Geologic and palaeomagnetic constraints on the formation of weathered profiles near Inverell, Eastern Australia. Palaeogeography, Palaeoclimatology, Palaeoecology, 126, 211-225.

Ali, J.R. \& Aitchison, J.C. 2000. Significance of paleomagnetic data from the oceanic Poya Terrane, New Caledonia, for SW Pacific tectonic models. Earth and Planetary Science Letters, 177, 153-161.

Ali, J.R. \& HALL, R. 1995. Evolution of the boundary between the Philippine Sea Plate and Australia: paleomagnetic evidence from eastern Indonesia. Tectonophysics, 251, 251-275.

Aubouin, J., Mattauer, M. \& Allègre, C. 1977. La couronne ophiolitique periaustralienne: un charriage océanique représantatif des stades précoces de l'évolution alpine. Comptes Rendus de l'Académie des Sciences, Série D, 285, 953-956.

Ballance, P.F., Ablaev, A.G. \& Pushchin, I.K. ET AL. 1999. Morphology and history of the Kermadec trench-arc-backarc basin-remnant arc system at 30 to $32^{\circ} \mathrm{S}$ : geophysical profile, microfossil and $\mathrm{K}-\mathrm{Ar}$ data. Marine Geology, 159, 35-62.

BennetT, M.C. 1976. The ultramafic-mafic complex at North Cape, northernmost New Zealand. Geological Magazine, 113, 61-76.

Brook, F.J., IsAac, M.J. \& Hayward, B.W. 1988. Geology of Autochthonous and Allochthonous Strata in the Omahuta Area, Northern New Zealand. New Zealand Geological Survey Record, 32.

Brothers, R.N. \& Delahoye, M. 1982. Obducted ophiolites of North Island, New Zealand: origin, age, emplacement and tectonic implications for Tertiary and Quaternary volcanicity. New Zealand Journal of Geology and Geophysics, 25, 257-274.

Cabanis, B. \& Lecolle, M. 1989. Le diagramme La/10-Y/25-Nb/8: un outil pour the discrimination des séries volcaniques et la mise en évidence des processus de mélange et/ou de contamination crustale. Comptes Rendus de l'Académie des Sciences, Série II, 309, 2023-2029.

CANDE, S.C. \& KENT, D.V. 1995. Revised calibration of the geomagnetic polarity time scale for the Late Cretaceous and Cenozoic. Journal of Geophysical Research, 100B, 6093-6095.

CAssidy, J. 1993. Tectonic implications of paleomagnetic data from the Northland ophiolite, New Zealand. Tectonophysics, 223, 199-211.

Coleman, R.G. \& Donato, M.M. 1979. Oceanic plagiogranite revisited. In:
Barker, F. (ed.) Trondhjemites, Dacites and Related Rocks. Developments in Petrology, 6, 149-168.

Collot, J.-Y. \& Davy, B. 1998. Forearc structures and tectonic regimes at the oblique subduction zone between the Hikurangi Plateau and the southern Kermadec margin. Journal of Geophysical Research, 103B, 623-650.

Compston, W., Williams, I.S. \& Meyer, C. 1984. U-Pb geochronology of zircons from lunar breccia 73217 using a sensitive high mass-resolution ion microprobe. In: Proceedings of the 14th Lunar Science Conference. Journal of Geophysical Research, 89B, 525-534.

Davey, F.J. 1982. The structure of the South Fiji Basin. Tectonophysics, 87, $185-241$.

Davis, H.L. 1971. Peridotite-Gabbro-Basalt Complex in Eastern Papua: an Overthrust Plate of Oceanic Mantle and Crust. Bureau of Mineral Resources of Australia, Bulletin, 128.

FAlvey, D.A. \& MutTer, J.C. 1981. Regional plate tectonics and the evolution of Australia's passive continental margins. Bureau of Mineral Resources, Journal of Australian Geology and Geophysics, 6, 1-29.

FARnELl, E.G. 1973. Geology of the Cape Reinga area, Northland. MSc thesis, University of Auckland.

Fisher, R.A. 1953. Dispersion on a sphere. Proceedings of the Royal Society of London, Series A, 217, 295-305.

Floyd, P.A., Yaliniz, M.K. \& Goncuoglu, M.C. 1998. Geochemistry and petrogenesis of intrusive and extrusive ophiolitic plagiogranites, Central Anatolian Crystalline Complex, Turkey. Lithos, 42, 225-241.

Gaina, C., Muller, D.R., Royer, J.-Y., Stock, J., Hardebeck, J. \& Symonds, P.A. 1998. The tectonic history of the Tasman Sea: a puzzle with 13 pieces. Journal of Geophysical Research, 103B, 12413-12433.

HALl, R. 2002. Cenozoic geological and plate tectonic evolution of SE Asia and the SW Pacific: computer-based reconstructions, model and animations. Journal of Asian Earth Sciences, 20, 353-431.

Hanson, J. A. 1991. Mylonitic fabric in Tangihua Volcanics: Camp Bay Northland. MSc thesis, University of Auckland.

Hayward, B.W., Black, P.M. \& SMith, I.E.M. et AL. 2001. K-Ar ages of early Miocene arc-type volcanoes in northern New Zealand. New Zealand Journal of Geology and Geophysics, 44, 285-311.

Hollis, C.J. \& Hanson, J.D. 1991. Well preserved late Paleocene radiolaria from Tangihua Complex, eastern Northland. Tane, 33, 65-76.

Hopper, D.J. \& SMith, I.E.M. 1996. Petrology of the gabbro and sheeted basaltic intrusives at North Cape, New Zealand. New Zealand Journal of Geology and Geophysics, 39, 389-402.

HuGHES, W.S. 1966. Igneous rocks from the northern Wairoa district. MSc thesis, University of Auckland.

IsaAC, M.J., Brook, F.J. \& Hayward, B.W. 1988. The Cretaceous Sequence at Whatuwhiwhi, Northland, New Zealand, and its Paleogeographic Significance. New Zealand Geological Survey Record, 26.

Kamp, P.J.J. 1986. Late Cretaceous-Cenozoic tectonic development of the southwest Pacific region. Tectonophysics, 121, 225-251.

KING, P.R. 2000. Tectonic reconstructions of New Zealand: $40 \mathrm{Ma}$ to the present. New Zealand Journal of Geology and Geophysics, 43, 611-638.

KirschVinK, J.L. 1980. The least squares line and plane analysis of palaeomagnetic data. Geophysical Journal of the Royal Astronomical Society, 62, 699-718.

KnitTel, U. \& Oles, D. 1995. Basaltic volcanism associated with extensional tectonics in the Taiwan-Luzon island arc: evidence for non-depleted sources and subduction zone enrichment. In: Smellie, J.L. (ed.) Volcanism Associated with Extension at Consuming Plate Margins. Geological Society, London, Special Publications, 81, 53-75.

Lanphere, M.A. \& Dalrymple, G.B. 1978. The use of ${ }^{40} \mathrm{Ar} /{ }^{39} \mathrm{Ar}$ data in the evaluation of disturbed $\mathrm{K}-\mathrm{Ar}$ systems. US Geological Survey Open-File Report, 78-701, 241-243.

Larsen, J.M. \& PARKer, R.J. 1989. Petrology and tectonic significance of igneous rocks from the Ahipara Tangihua Massif, Northland, New Zealand. In: SPÖRLI, K.B. \& KeAR, D. (eds) Geology of Northland: Accretion, Allochthons and Arcs at the Edge of the New Zealand Micro-continent. Royal Society of New Zealand Bulletin, 26, 145-153.

LARSEN, J.M. \& SpörLI, K.B. 1989. Structure of the Tangihua ophiolites at Ahipara, Northland, New Zealand. In: Spörli, K.B. \& KeAr, D. (eds) Geology of Northland: Accretion, Allochthons and Arcs at the Edge of the New Zealand Micro-continent. Royal Society of New Zealand Bulletin, 26, $137-144$.

LitTle, T.A. \& RoberTs, A.P. 1997. Distribution and mechanism of Neogene to present-day vertical axis rotations, Pacific-Australian plate boundary zone, South Island, New Zealand. Journal of Geophysical Research, 102B, 2044720468.

Lo, C.H. \& LEE, C.Y. 1994. ${ }^{40} \mathrm{Ar} /{ }^{39} \mathrm{Ar}$ method of $\mathrm{K}-\mathrm{Ar}$ age determination of geological samples using Tsing-Hua Open-Pool (THOR) Reactor. Journal of the Geological Society of China, 37, 143-164.

Lo, C.H., Onstott, T.C. \& LeE, T. 1994. An assessment of ${ }^{40} \mathrm{Ar} /{ }^{39} \mathrm{Ar}$ dating for the whole-rock volcanic samples from the Luzon Arc near Taiwan. Chemical 
Geology, 114, 157-178.

Malahoff, A., Feden, R.H. \& Fleming, H.S. 1982. Magnetic anomalies and tectonic fabric of marginal basins north of New Zealand. Journal of Geophysical Research, 87B, 4109-4125.

Malpas, J., Spörli, K.B., Black, P.M. \& SMith, I.E.M. 1992. Northland ophiolite, New Zealand, and implications for plate tectonic evolution of the southwest Pacific. Geology, 20, 149-152.

Malpas, J., Smith, I.E.M. \& Williams, D. 1994. Comparative genesis and tectonic setting of ophiolitic rocks of the South and North Islands of New Zealand. In: Ishiwatari, A., Malpas, J. \& Ishizuka, H. (eds) Circum-Pacific Ophiolites. VSP, Utrecht, 29-46.

McFadden, P.L. \& ReID, A.B. 1982. Analysis of palaeomagnetic inclination data. Geophysical Journal of the Royal Astronomical Society, 69, 307-319.

Meffre, S., Aitchison, J.C. \& Crawford, A.J. 1996. Geochemical evolution and tectonic significance of boninites and tholeiites from the Koh ophiolite, New Caledonia. Tectonics, 15, 67-83.

Meschede, M. 1986. A method of discriminating between different types of midocean ridge basalts and continental tholeiites with the $\mathrm{Nb}-\mathrm{Zr}-\mathrm{Y}$ diagram. Chemical Geology, 56, 207-218.

Mortimer, N. \& PARKinson, D. 1996. Hikurangi Plateau: a Cretaceous large igneous province in the southwest Pacific. Journal of Geophysical Research, 101B, 687-696.

NaKamura, N. 1974. Determination of REE, Ba, Fe, Mg, $\mathrm{Na}$ and $\mathrm{K}$ in carbonaceous and ordinary meteorites. Geochimica et Cosmochimica Acta, 38, 757-775.

Nicholson, K.N., Black, P.M. \& Picard, C. 2000a. Geochemistry and tectonic significance of the Tangihua Ophiolite Complex, New Zealand. Tectonophysics, 321, 1-15.

Nicholson, K.N., Picard, C. \& Black, P.M. 2000b. A comparative study of Late Cretaceous ophiolitic basalts from New Zealand and New Caledonia: implications for the tectonic evolution of the SW Pacific. Tectonophysics, 327, 157-171.

NorRis, K. \& CHAPPEL, B.W. 1977. X-ray fluorescence spectrometry. In: Zussman, J. (ed.) Physical Methods in Determinative Mineralogy. Academic Press, New York, 201-272.

ODIN, G.S. ET AL. 1982. Interlaboratory standards for dating purposes. In: ODIN, G.S. (ed.) Numerical Dating in Stratigraphy. Wiley \& Sons, Chichester, 123150.

Oxburgh, E.R. 1972. Flake tectonics and continental collision. Nature, 239, 202-204.

Parrot, J.F. \& Dugas, F. 1980. The disrupted ophiolitic belt of the Southwest Pacific: evidence of an Eocene subduction zone. Tectonophysics, 66, 349-372.

Pearce, J.A. 1982. Trace element characteristics of lavas from destructive plate boundaries. In: Thorpe, R.S. (ed.) Andesites. Wiley, Chichester, 230-249.

Pedersen, R.B. \& Malpas, J. 1984. The origin of oceanic plagiogranites from the Karmoy ophiolite, western Norway. Contributions to Mineralogy and Petrology, 88, 36-52.

RAIT, G.A. 2000. Thrust transport directions in the Northland allochthon, New Zealand. New Zealand Journal of Geology and Geophysics, 43, 271-288.
Rait, G.J., Chanier, F.R. \& Waters, D.W. 1991. Landward- and seaward-directed thrusting accompanying the onset of subduction beneath New Zealand. Geology, 19, 230-233.

RudDock, R. \& SPÖRLI, K.B. 1989. Relation between intrusion and tectonics in the Miocene Karikari Pluton, Northland, New Zealand. In: SPÖRLI, K.B. \& KeAR, D. (eds) Geology of New Zealand. Royal Society of New Zealand Bulletin, 26, 195-204.

Schettino, A. \& SCOTESE, C.R. 2001. http://www.itis-molinari.mi.it/geo.html

Smith, I.E.M. RudDock, R.S. \& DAY, R.A. 1989. Miocene arc-type volcanic/ plutonic complexes of the Northland Peninsula, New Zealand In: SpörLI, K.B. \& Kear, D. (eds) Geology of Northland: Accretion, Allochthons and Arcs at the Edge of the New Zealand Micro-continent. Royal Society of New Zealand Bulletin, 26, 205-213.

Sun, S.S. \& McDonough, W.F. 1989. Chemical and isotopic systematics of oceanic basalts: implications for mantle composition and processes. In: SAunders, A.D. \& Norry, M.J. (eds) Magmatism in the Ocean Basins. Geological Society, London, Special Publications, 42, 313-345.

Sutherland, R. 1995. The Australia-Pacific boundary and Cenozoic plate motions in the SW Pacific: some constraints from GEOSAT data. Tectonics, 14, 819-831.

Thompson, G.M., Malpas, J. \& Smith, I.E.M. 1997. The geochemistry of tholeiitic and alkalic plutonic rocks within the Northland ophiolite, northern New Zealand: magmatism in a back arc basin. Chemical Geology, 142, 213-223.

VAN DER LINGEN, W.J.M. 1967. Structural relationships in the Tasman Sea and the southwest Pacific Ocean. New Zealand Journal of Geology and Geophysics, 10, 1280-1301.

VAN DER Voo, R. 1990. The reliability of paleomagnetic data. Tectonophysics, 184, $1-9$.

Walcott, R.I. 1978. Present tectonics and Late Cenozoic evolution of New Zealand. Geophysical Journal of the Royal Astronomical Society, 52, $137-164$.

Watts, A.B., Weissel, J.K. \& Davey, F.J. 1977. Tectonic evolution of the South Fiji marginal basin. In: Talwani, M. \& Pitman, W.C. (eds) Island Arcs, Deep Sea Trenches and Back Arc Basins. American Geophysical Union Series, 1, 419-427.

Whatтам, S.A. 2003. Evolution of the Northland ophiolite: geochemical, geochronological and palaeomagnetic constraints. $\mathrm{PhD}$ thesis, University of Hong Kong.

Wood, D.A. 1980. The application of the Th-Hf-Ta diagram to problems of tectonomagmatic classification and to establishing the nature of crustal contamination of basaltic lavas of the British Tertiary volcanic province. Earth and Planetary Science Letters, 50, 11-30.

YAN, C.Y. \& KROENKE, L.W. ET AL. 1993. A plate reconstruction of the southwest Pacific, 0-100 Ma. In: Berger, W. (ed.) Proceedings of the Ocean Drilling Program, Scientific Results, 130. Ocean Drilling Program, College Station, TX, 697-709.

ZiJderveld, J.D.A. 1967. AC demagnetization of rocks: analysis of results. In: Collinson, D.W., Creer, K.M. \& Runcorn, S.K. (eds) Methods in Palaeomagnetism. Elsevier, New York, 254-286. 